\title{
Main trends in application of novel natural additives for food production
}

\section{Olena Stabnikova, Andrii Marinin, Viktor Stabnikov}

\author{
National University of Food Technologies, Kyiv, Ukraine
}

Keywords:

Food

Natural

Additives;

Health value

Plant substitute

\section{Article history:}

Received 20.02.2021

Received in revised

form 19.06.2021

Accepted 30.09.2021

\section{Corresponding \\ author:}

Olena Stabnikova

E-mail:

stabstab6@gmail.com

DOI: $10.24263 / 2304-$

974X-2021-10-3-8

\section{Abstract}

Introduction. The review considered the major novel natural additives for food products.

Materials and methods. Analysis of scientific knowledge about novel natural additives for food products has been done.

Results and discussion. In recent years, a lot of research has been conducted to study the application of novel natural additives such as plants with pharmaceutical properties, plant materials with antioxidant activity, essential plants oils, extracts from plant materials seaweeds, seeds products, different gluten-free cereal and pseudo-cereals flours for replacement of gluten in bakery products, dietary fibers, edible coatings materials of plant origins, in preparation of different traditional food products. The main goal of this trend is to improve the health value of these products without significant change of their technological parameters and acceptability by consumers. These new trends include replacement of animal fat by low calorie materials with high content of fatty acids in meat products; use of plant materials with antioxidant properties, for example, extracts from fruits, vegetables, spices, and herbs containing phenolic substances instead of synthetic antioxidants in food preparation; replacement of gluten in bakery products with plant free gluten substitutes; use of plant essential oils as natural preservatives to prolong shelf-life of food products. Some researches concern the application of plant additives with specific pharmacological effect to produce food products useful for prevention of different diseases or supplying the consumers with needed quantities of essential for the health state substances. The present study reviews the main trends in application of novel natural additives used recently in food production.

Conclusions. Review information can be valuable for researchers and managers to prioritize the research and innovation directions in enhancement of food products. 


\section{Introduction}

In recent years, a lot of research has been conducted to study novel natural additives to improve the health value of different traditional food products. These new trends include replacement of animal fat by low calorie material with high content of fatty acids in meat products (seed oils, for example); replacement of gluten in bakery products with plant free gluten substitutes; use of addition of plant material with antioxidant properties instead of chemical preservatives to prolong shelf-life of food; an application of edible coating with incorporated natural antioxidant and antimicrobial agents in different food products to protect their properties and extend time of storage. Application of plant additives with specific pharmacological properties was proposed to produce food products useful for prevention of different diseases or supplying the consumers with needed quantities of essential for the health state substances.

The aim of the present study was to review the main trends in application of novel natural additives used recently in food production.

\section{Trend 1. Plant additives with pharmaceutical properties for food products}

A new trend in food production is an addition to traditional food products of different plant additives which are used for medical purposes and have pharmacological properties. For example, a tree-shaped plant Bail fruit (Aegle marmelos L.), widely distributed in South East Asia, is known as one which has pharmacological properties and traditional medical usage and is also consumed as a food. It was reported that Bael fruit has cardio-protective, radio-protective, gastro-protective and hepato-protective effects, as well as antioxidant, antibacterial, antiviral and anti-diabetic properties (Mulyaningsih et al., 2020; Sarkara et al., 2020; Venthodika et al., 2021). Numerous scientific researches partially along with clinical trials are providing now to establish the ways for usage of $A$. marmelos for different food products such as bael juice, syrups, beverages, jam, toffee, and candy (Mali et al., 2020; Ullikashi et al., 2017). However, pharmacological effects of food products based on bail fruit as well as recommended dosage of its consumption should be studied in further research (Venthodika et al., 2020).

Moringa oleifera is an example of plants with pharmacological properties which are proposed for food preparation (Milla et al., 2021). This plant is considered a source of nutritional and bioactive compounds such as fibres, phenolic compounds, fatty acids, vitamins, minerals and functional peptides, and many authors proposed its application in preparation of functional food products mainly in meats, bakery, juices and sandwiches to improve their nutritional and health value. Only for bakery products, leaf powder from Moringa oleifera is proposed to be used for preparation of cookies (Chizoba, 2014), bread (Bolarinwa et al., 2019; Ogunsina et al., 2011; Rabie et al., 2020; Sengev et al., 2013), brownie (Castro-Lopez et al., 2017); rice crackers (Manaois et al., 2013), snack (Devisetti et al., 2015), and cakes (Kolawole et al., 2013).

Lycium plants attract attention by their high nutrition and medicinal value (Jiang et al., 2021). Different parts of Lyceum plants, namely berries, leaves and root barks, are used for a long time in traditional Chinese medicine in the treatment of age related diseases such as atherosclerosis and diabetes (Potterat, 2010). Meanwhile, Lycium fruit (Goji berries) is widely consumed as a food, for example in Chinese soups and as herbal tea (Ma et al., 2019). Berries, leaves and root barks of Lycium plants contain 84 different phenolics (Qian et al., 
2017) and other bioactive substances such polysaccharides and terpenes. Lycium fruit can be consumed as dried whole berries and as berries incorporated in meat products, flours and beverages. Addition of Lycium berry puree (2.5 and/or 5\%) and chia seeds in beef burger increased its antioxidant ability and decreased lipid peroxidation (Antonini et al., 2020). This new product was accepted by consumers as functional burgers. Partially replacement of wheat flour up to $40 \%$ with goji berry by-product that is left after production of goji juice/concentrate resulted in significant increase of protein, free phenolic, insoluble and soluble dietary fibers contents in the muffins and cookies (Bora et al., 2019). White chocolate added with Lycium berry was positively evaluated by consumers (Ferreira et al., 2017). Incorporation of Lycium barbarum berries into yogurt improved it's the antioxidant properties and enriched biological value (Taneva and Zlatev, 2020).

\section{Trend 2. Essential plants oils for food preservation}

Application of plant essential oils as natural preservatives is a new trend in food processing. Essential oils are concentrated volatile compounds extracted from different plant materials such as leaves, fruits, flowers, roots, seeds, wood and have been extracted from such plants as sweet orange, lemon, lavender, oregano, rosemary, sage, ginger, clove, cinnamon, curcumin, spearmint, pomegranate peel, grape seed, basil, coriander, garlic cloves, eucalyptus and myrtle. A lot of essential oils are generally recognized as safe (GRAS) and are permitted for use in food products. One of the important properties of essential oils is ability to suppress microbial growth, and this antimicrobial activity could be used in food preservation instead of conventional chemical agents (Hyldgaard et al., 2012). It was shown that tested essential oils had very low minimal inhibitory concentration against different bacteria species estimated as $0.05-60 \mu \mathrm{g} / \mathrm{mL}$ (Aumeeruddy-Elalfi et al., 2015; Bajera et al., 2017). However, the antimicrobial effect of essential oils can be changed and depends on composition of food and used food additives (Garcia-Diez et al., 2017).

It was shown that the addition of the spice nutmeg (Myristica fragrans) essential oil in concentration $20 \mathrm{mg} / \mathrm{L}$ increased oxidative and microbial stability and extended shelf life of cooked sausages (Sojic et al., 2015). Essential oils as food additives are often used with combinations of other natural preservatives. For example, the addition of Zataria multiflora Boiss essential oil and grape extract in quantity $0.1 \%$ and $0.2 \%$, respectively, in raw buffalo patties decreased the level of lipid oxidation and extended the shelf life of tested meat products. The presence of essential oil and grape seed extract demonstrated strong antimicrobial effect in raw buffalo patties inoculated with Listeria monocytogenes (Tajik et al., 2015). Combination of cinnamon essential oil and grape seed extract added to Lyonertype sausages improved their odor and color scores, extended their shelf life during refrigerated storage and inhibit the growth of Clostridium perfringens in artificially contaminated samples (Aminzare et al., 2018).

Essential oils could be applied as natural antimicrobial and antioxidant agents for fish and other seafood to protect them from microbial spoilage and lipid oxidation and prolong the shelf life (Hassoun and Coban, 2017). To increase effectiveness of treatment, combinations of different essential oils could be used. However, it is necessary to study possible cytotoxicity and toxicity of used essential oils.

It was proposed to use edible microcapsules containing essential oils, especially the starch microcapsules, for prolongation of the shelf life of food instead of chemical preservatives (Ju et al., 2020). These microcapsules are environmentally friendly; ensure slow release of essential oil, and protect food products from the flavor influence. 


\section{- Food Technology -}

Microencapculated essential oil from Perilla frutescens L. Britt had good antibacterial activity and was recommended to be used for strawberry preservation and prolongation of the shelf life (Li et al., 2018).

\section{Trend 3. Extracts from plant materials for replacement of synthetic antioxidants}

Extracts from fruits, vegetables, spices, and herbs usually contain phenolic substances which ensure their strong antioxidizing activity. So, these natural products could replace synthetic antioxidants in preparation of food (Aminzare et al., 2019).

Extracts of plant Roselle (Hibiscus sabdariffa L.), used in traditional folk medicine in many countries, are rich in polyphenols such as polysaccharides, anthocyanins, and organic acids (Riaz and Chopra, 2018). Compounds from these extracts have antioxidant and antibacterial properties and can be used as natural additives (Marquez-Rodríguez et al., 2020). A phenolic extract obtained from hibiscus calyces possessed antimicrobial activity against such foodborne pathogens as Listeria monocytogenes Salmonella enterica, Escherichia coli, Staphylococcus aureus, and Bacillus cereus and being using for meat products preparation showed preservation effect. Spraying of ethanolic or phenolic extracts from hibiscus on beef steaks resulted in prolongation of the meat's shelf life (Marquez-Rodríguez et al., 2020). Generally, there are a lot of studies which propose using extracts from different fruits and vegetables as natural antioxidants for meat products. Some examples are shown in Table 1.

Table 1

Use of extracts from plant materials as natural antioxidants in meat products

\begin{tabular}{|l|l|l|}
\hline Extracts from & Meat product & References \\
\hline Acerola fruit & Beef patties & Realini et al., 2015 \\
\hline Guarana seed or Pitanga leaf & Lamb burgers & de Carvalho et al., 2019 \\
\hline Ginkgo leaves & Meat balls & Kobus-Cisowska et al., 2014 \\
\hline Hibiscus calyces & Beef steaks & Marquez-Rodriguez et al., 2020 \\
\hline Hyssop & Pork meat & Fernandez-Lopez et al., 2003 \\
\hline Lotus seed epicarp & Chinese sausage & Qi and Zhou, 2012 \\
\hline Mugwort and Rosemary & Pork patties & Hwang et al., 2016 \\
\hline Murraya koenigii berries & Meat batter & Kumar and Kumar, 2020 \\
\hline Red pitaya & Pork patties & Bellucci et al., 2021 \\
\hline Rosemary & Pork meat & Fernandez-Lopez et al., 2003 \\
\hline Uulam raja leaves & Beef patties & Reihani et al., 2014 \\
\hline Pitangueira leaves & Pork sausage & Luciano et al., 2021 \\
\hline
\end{tabular}

The addition of extract from acerola (Malpighia emarginata) extended the shelf life of beef patties by improving their lipid stability (Realini et al., 2015). Extracts from ulam raja leaves (Cosmos caudatus) and green tea extract incorporated in beef patties demonstrated a strong lipid oxidation inhibitory effect and an improvement in cooking yield and textural properties (Realini et al., 2014). The incorporation of mugwort (Artemisia vulgaris) extract, rosemary (Rosmarinus officinalis) extract and ascorbic acid added in quantity $0.05 \%$ each 
delayed oxidative deterioration and maintained quality of pork patties during their refrigerated storage (Hwang et al., 2016). Extract from less conventional plants, such as Pitangueira (Eugenia uniflora), was proposed to be added in fresh pork sausage to extend their shelf-life (Luciano et al., 2021). Extracts from rosemary or hyssop inhibited lipid oxidation, degradation of heme pigments, and slowed down metmyoglobin formation during cooking and storage (Fernandez-Lopez et al., 2003). Lotus (Nelumbo nucifera Gaertn) seed epicarp, the main by-product of lotus seed processing, is rich in polyphenols. Extracts from lotus seed epicarp being used for supplementation of pork homogenate which represented Chinese Cantonese sausage resulted in retarding of lipid oxidation (Qi and Zhou, 2012). Extract from Ginkgo (Ginkgo biloba) leaves added in pork meatballs inhibited lipid and cholesterol oxidation processes during 21 days of products refrigerated storage (KobusCisowska et al., 2014). The addition of red pitaya extract to pork patties improved consumer acceptance of these meat products due to improving colour and extended the shelf life of parties during storage at $2^{\circ} \mathrm{C}$ due to retarding the oxidative processes (Bellucci et al., 2021). The addition of encapsulation Murraya koenigii berries extract ensured higher oxidative stability of meat batter (Kumar and Kumar, 2020). Incorporation of guarana seed or pitanga leaf extracts delayed discoloration and ensured oxidative stability of the lamb patties during their refrigerated storage, meanwhile sensorial properties were not changed (de Carvalho et al., 2019).

It is known that berries contain a lot of phenolic compounds, especially anthocyanin. Extracts of such berries as bearberry (Arctostaphylos sp.), blueberry (Vaccinium sp.), blackberry (Rubus sp.), cloudberry (Rubus chamaemorus), cranberry (Vaccinium sp.), blackcurrant (Ribes nigrum), strawberry (Fragaria ananassa), and grape berries (Vitis sp.), contained antioxidant polyphenols, so, they were recommended to be used for stabilizing meat products instead of synthetic antioxidants (Lorenzo et al., 2018). Extract from cloudberry showed strong antioxidant activity due to presence of flavonoids and was recommended to be added to pork patties to prevent lipid oxidation in the cooked product (Rey et al., 2005).

Extract from herbs could be used for stabilization of oil that replaces fat in meat products. Chia oil was enriched with rosemary obtained with ultrasound-assisted extraction to ensure oil oxidative stability. This mixture was microencapsulated and used to replace $50 \%$ fat in burgers (Heck et al., 2018). The similar effect was observed when guarana seed and pitanga leaf extracts were added as natural antioxidants to lamp patties prepared with replacement of fat by chia oil emulsion (de Carvalho et al., 2019). It was shown that addition of mentioned plant extracts delayed discoloration of the lamb patties during storage at $2^{\circ} \mathrm{C}$, as well as lipid and protein oxidation, without changes of their sensorial properties. Replacement of $20 \%$ pork back with dietary fiber extracted from makgeolli lees did not decrease the quality of frankfurters with 30\% fat (Choi et al., 2014). Jaboticaba (Myrciaria jaboticaba (Vell.) Berg) is a Brazilian grape-like fruit. The addition of up to $0.5 \%$ of jabuticaba peel extract to bologna-type sausages improved their oxidation stability during storage due to extract antioxidant activity without affection of sensory quality (de Almeida et al., 2015).

Use of thuja (Thuja occidentalis) cones or peach (Prunus armeniaca) seeds extracts with the content of total phenolic compounds 0.8 and $0.2 \%$ by dry weight, respectively, were added in quantity $50 \mathrm{~mL}$ of extract to $1 \mathrm{~kg}$ of minced meat in raw chicken ground meat as antioxidants (Yogesh and Ali, 2014). Addition of these extracts inhibited lipid oxidation during chicken ground meat storage at $4^{\circ} \mathrm{C}$, increased water holding capacity and decreased cooking loss. However, authors noticed that Prunus family kernels and thuja cones contain compounds which could have toxic effects being consumed more, so further studies were 
needed to estimate the possibility of using these fruit extracts in meat preparation. Cinnamon (Cinnamomum Zeylanicum) essential oil contains phenolic and polyphenolic compounds and could be used in low concentrations $(0.02 \%$ and $0.04 \% \mathrm{v} / \mathrm{w})$ in preparation of Lyoner- type sausage to inhibit lipid oxidation and increase sausages chemical stability (Aminzare et al., 2015).

Natural polyphenols extracted from different plants have the potential to be used as antioxidant and antimicrobial agents instead of synthetic additives to preserve fish and fish product quality (Maqsood et al., 2013). There are also some researches concerned about their use as functional ingredients in meat and fish processing (Gokoglu, 2019; Patel, 2015).

Natural antioxidants can be added to edible oils to enhance their stability. For example, addition of essential oils from cinnamon or clove to hazelnut or poppy oils successfully prevented lipid oxidation and were recommended to be used instead of synthetic antioxidant butylated hydroxyanisole (Ozcan and Arslan, 2011).

Plant extracts could be used in the dairy products. It was shown that the extracts from such spices and herbs as cinnamon, cloves, garden cress, oregano and lemon grass demonstrated antibacterial activity against foodborne pathogens including Listeria monocytogenes, Salmonella typhimurium, Staphylococcus aureus, and Escherichia coli. Being incorporated in cheeses they also enhanced taste, odor, color and total quality of the product (Tayel et al., 2015). Effectiveness of five spice and herb extracts used against development of three foodborne pathogens in cheese at room temperature $23^{\circ} \mathrm{C}$ was demonstrated (Shan et al., 2011). The decrease of pathogen numbers and the inhibition of lipid oxidation were observed in cheese treated with these extracts.

Plant extract can be incorporated in dairy products replacing synthetic additives to improve their antioxidant activity. Thus, cottage cheese added with aqueous extracts of fennel (Foeniculum vulgare Mill) or chamomile (Matricaria recutita L.) microencapsulated in alginate showed higher antioxidant activity after the 7 th day of storage in comparison with control prepared without plant extracts (Caleja et al., 2016). Combination of essential oils and plant extracts is an attractive alternative for synthetic preservatives in cheese production to ensure microbiological safety of the products (Gouvea et al., 2017). However, the influence of their incorporation on activity of lactic bacteria and the sensory characteristics of products should be studied as well as studies concerning more effective combinations of different essential oils and plant extracts.

Cinnamon leaf and bark essential oils added in quantity of $0.5 \%$ in strawberry shakes showed strong antimicrobial activity against Salmonella typhimurium and Listeria monocytogenes and completely inhibited both bacteria after 8 days storage at $4{ }^{\circ} \mathrm{C}$ (Brnawi et al., 2018).

Natural antioxidants were also proposed to be used in bakery products. For example, the incorporation of fennel and chamomile aqueous extracts rich in phenolic compounds in biscuits ensured similar antioxidant activity as a synthetic antioxidant, the butylated hydroxylanisole, widely used in food production (Caleja et al., 2017).

Despite evident beneficial effects on food stability and its protection from microbial spoilage and oxidation, more studies should be conducted to prove safety of essential oils or plant's extracts in food production and evaluate possible side effects (Lourenço et al., 2919; Ribeiro-Santos et al., 2017). New antioxidants to be used in food production should be approved by the European Food Safety Authority (EFSA) or by the United States Food and Drug Administration. A new food additive must be safety evaluated by (1) its chemistry and specifications; (2) existing authorizations and evaluations (data of previous risk assessments); (3) proposed uses and exposure assessment, and (4) toxicological studies (ANS, 2012). 


\section{Trend 4. Application of seaweeds in food nutrition}

Edible seaweeds (macroalgae) are presently a subject of many investigations. Macroalgae have been a part of local nutrition in Asian East and Southeast countries from ancient times, and the health benefit of seaweed and seaweed extract is shown in different studies (Brownlee et al., 2012; Shannon and Abu-Ghannam, 2019). Seaweeds or seaweeds extracts were proposed to be used to increase health value and shelf life of different food products as well as for preparation of low-fat products with decreased content of calories and saturated fatty acids and improve overall quality of foods (Roohinejad et al, 2017). Edible seaweeds are considered to be a good source of dietary fibers, peptides, phlorotannins, essential amino acids, antioxidants, vitamins, unsaturated fatty acids, carotenoids and abundant minerals that can be incorporated in meat, fish, bakery and others food products as a source of nutrient as well as a source of compounds needed to be consumed by people suffering from a wide spectrum of disorders or diseases (Lordan et al., 2011; Fitzgerald et al., 2014; Cardo et al., 2014; 2015).

There is a lot of research about using macroalgae, or extracts from them to create new products which could be used by the population suffering from different cardiovascular diseases (Cardoso et al., 2015). Mainly meat-based products with addition of seaweeds were proposed and studied as functional foods for populations with cardiovascular-health problems. The main aim of seaweed incorporation in the meat products is to improve the composition of fatty acids and to reduce the content of cholesterol, salt and fat. To improve fatty acid content of such meat products as patties, frankfurters and steaks seaweeds wakame Undaria pinnatifida, nori Porphyra umbilicalis, and sea spaghetti Himanthalia elongata were added as a source of bioactive substances with simultaneous reduction of content of sodium and fat (5\% of each seaweed to pork meat) (Cofrades et al., 2017). These meat products were tested on male rats to study their health effects. The authors indicate that every kind of algae has its own effect based on its composition, and should be subject of individual study.

Research done in Korea with volunteers showed that addition of sea tangle Laminaria japonica to chicken and pork patties had improved postprandial plasma glucose and lipids profiles in borderline-hyperlipidemic adults (Lim et al., 2013).

To reduce sodium content in meat products, addition of selected seaweeds (Porphyra umbilicalis, Palmaria palmate, Himanthalia elongata or Undaria pinnatifida) in quantity 1\% $(\mathrm{w} / \mathrm{w})$ in reformulated frankfurters were conducted to replace salt. The most promising results were obtained when seaweed H. elongate was used (Vilar et al., 2020).

Edible seaweeds have been a source of selenium and iodine (Cherry et al., 2019; Circuncisao et al., 2018) which are needed to ensure optimal thyroid function (Schomburg and Kohrle, 2008). Preparation of functional meat products enriched with seaweeds Cystoseira or Fucus ( $2 \%$ by dry weight to raw stuff) was proposed to supply the population with needed daily quantities of iodine and selenium (Kryzhova et al., 2021).

Bakery products are other subjects to be enriched with microalgae. Seaweeds Lemna minor or Ulva rigida were studied as additives in bread preparation to extend its shelf-life (Kilınc et al., 2013). A renin-inhibitory protein of edible seaweed Palmaria palmata was incorporated in bread at quantity 4\% (Fitzgerald et al., 2011). It was shown that the bioactivity was evident after bakery procedure but no significant changes in texture or sensory properties were observed. The addition of seaweed Ascophyllum nodosum, 4\% per loaf, reduced energy intake at a meal but not nutrient uptake (Hall et al., 2012).

Effect of addition of Fucus vesiculosus seaweed powder to wheat flour on dough and bread properties showed that it could be added at maximum of $4 \%$ (flour basis) without 
deterioration of enriched breads (Arufe et al., 2018). Further increase of quantity of seaweed powder added to dough resulted in significantly increasing of density and crumb firmness and changing of bread crust colour.

For the last few years some beverages prepared with microalgae or extract from them were developed. These beverages were proposed to be used as health drinks. Beverage prepared from macroalgae sea trumpet possessed strong antioxidant properties correlated with the contents of polyphenols (Nagai and Yukimoto, 2003). Beverages prepared from this sea algae had angiotensin I-converting enzyme inhibitory activities: sea trumpet $(0.625 \mathrm{mg}$ dry matter $/ \mathrm{mL})$, hizikia $(7.79 \mathrm{mg}$ dry matter $/ \mathrm{mL})$, and wakame $(26.4 \mathrm{mg}$ dry matter $/ \mathrm{mL})$ and could be used not only as drinks supplying minerals, but also to suppress the hypertensive activity of angiotensin I (Nagai et al., 2016). To prepare a beverage for the prevention of hypertension, seaweed Hizikia fusiforme was used as a main part of composition (Kim, 2008).

So, seaweeds could have wide applications in preparation of food products with certain health benefits. However, when seaweed is added to a food product as a source of a certain component it is necessary to estimate possible effects of other substances presented in this seaweed. For example, seaweed Laminaria contained too much selenium and iodine to be recommended as additives for meat products in concentrations higher than 1-2\% (Kryzhova et al., 2021). The content of seaweed added to products should be higher regulated because health effects could depend on the quantity of seaweed consumed. For example, consumption of parties with cooked rice containing sea tangle powder substituted, $2.5 \%$ of meat, by women volunteers improved blood glucose concentration; meanwhile patties substituted with cooked rice containing $25 \%$ or $50 \%$ sea tangle powder might ameliorate plasma lipid profiles (Oh and Lim, 2011). So, the health benefits of new products should be checked before they could be recommended for the food market. Physico-chemical and sensory quality of food product depends on the quantity of added seaweed. Addition of powder of Fucus or Cystoseira in quantity $2 \%$ to raw stuff in preparation of different meat products did not significantly change their sensory properties (Kryzhova et al., 2021). Characteristics of pork parties with sea tangle powder of Laminaria japonica, $1-3 \%$, were similar to the control parties (Choi et al., 2012). Meanwhile, a comparison of the quality of the breakfast sausage containing $1,2,3$, and $4 \%$ powder of Lamina japonica showed that sausage with $1 \%$ had the highest overall acceptability (Kim et al., 2010). The addition of $2-8 \%$ dried red seaweed Kappaphycus alvarezii powder to wheat flour increased the water absorption of the dough and decreased its stickiness properties (Mamat et al., 2014). However, no significant difference in the slickness values of the dough added with different quantities of seaweed was observed. The firmness of the bread increased over the period of storage and positively correlated with the percentage of seaweed powder added to flour. The quality of produced bread was affected by the amount of added seaweed (Figure 1). The addition of seaweed decreased the bread density, the volume of bread and increased the yellowness of the bread crumb obtained. 


\section{- Food Technology -}

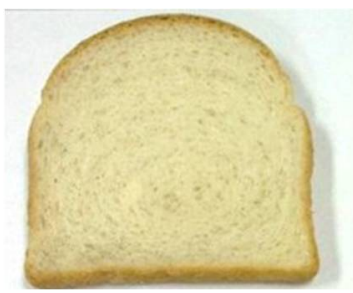

F1

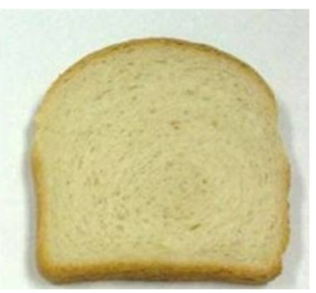

F2

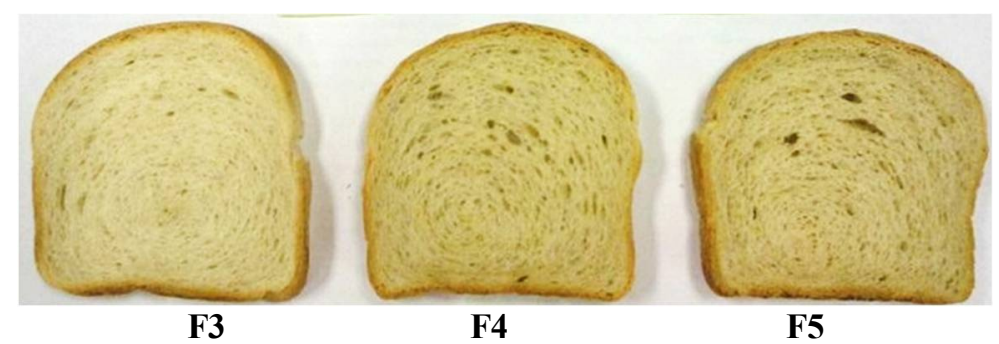

Figure 1. Bread produced with seaweed powder, $\%$ : 0 (F1), $2 \%$ (F2), 4\% (F3), 6\% (F4), 8\% (F5). (Adapted from Mamat et al., 2014).

\section{Trend 5. Plant seeds as additives to food products}

Seeds of different plants have specific chemical compositions and in recent years a lot of researches studying the possibility of their usage for preparation of functional food products were published. Chia seed has been in the focus of many studies. Chia (Salvia hispanica L.) originally was grown in Mexico and Guatemala and the nutritional properties and health-promoting properties of chia seeds are known, especially, due to oil content (between $30 \%$ and 33\%) with high percentage of unsaturated fatty acid (around $80 \%$ of total acid value) and presence of omega- $3 \alpha$-linolenic acid and other polyunsaturated fatty acids. Chia seed is also a source of dietary fiber (up to 38\%), minerals (4-5\%), and protein (1525\%) (Kulczynski et al., 2019; da Silva et al., 2017). The seeds are characterized also by high contents of polyphenols and antioxidants (Hrncic et al., 2020). For its nutrient and health values chia seed was announced as plant material which is "The new golden seed for the $21 \mathrm{st}$ Century" (Orona-Tamayo et al., 2017).

The use of chia seeds to enhance the quality of food products has been studied intensively. The addition of chia seeds to beef burgers doubled or tripled the content of polyunsaturated fatty acids, increased the content of polyphenols and antioxidant activity (Antonini et al., 2020). Hedonistic tests conducted for different age groups of population showed acceptability of this food product and indicated its potential application as a functional burger.

Chia seeds were added to different bakery products to improve their nutritional value. It was shown that addition of chia seed mucilage in bread and cakes for replacement up to $50 \%$ of fat did not affect significantly technological and organoleptic characteristics of healthier bakery products (Fernandes et al., 2017).

The addition of chia flour to the biscuits improved not only the nutritional value of the product, but also increased the antioxidant capacity, content of phenolic compounds, protein, 
fiber and polyunsaturated fatty acids; however, contamination process was increased, so the shelf life of the product was decreased (Mesias et al., 2016).

It was shown that reduction of the amount of hydrogenated vegetable fat with chia seeds or chia flour in breads increased the levels of fibers and polyunsaturated fatty acids, mainly omega-3, but affected the technological quality of the loaves decreasing the specific volume and the total score values. However, both types of bread obtained a high level of acceptability by consumers, meanwhile bread with the addition of chia flour had a higher index of purchase intent than the bread with chia seeds (Coelho et al., 2015).

It was proposed to use different seeds to be incorporated in the different bakery products. Pumpkin seeds could serve as a source of proteins with high content of tryptophan, carotenoids, protein, minerals, including zinc, iron, magnesium and manganese, fiber and omega 3 and omega 6 fatty acids. Pumpkin seed products were added to wheat flour to produce blends with protein levels of $15,17,19$ and $21 \%$ for loaves of breads production (ElSoukkary, 2001); it was recommended the addition of pumpkin seeds powder to wheat flour up to $15 \%$ to improve nutrition value and sensory quality of cookies (Alshehry, 2020); 50\% replacement of wheat flour with pumpkins seed flour was proposed in preparation of cupcakes (Batista et al., 2018). Pumpkin seeds flour was recommended to be added in gravy to increase its nutrition and health value (Sharma and Sarla, 2017).

Flaxseed (Linum usitatissimum, L.) has high contents of protein and fiber and low contents of carbohydrate and fat, contains such compounds as phenolic acids, lignans and flavonoids with antioxidant characteristics, minerals especially $\mathrm{Ca}, \mathrm{K}, \mathrm{P}$ and $\mathrm{Mg}$ (Khaled et al., 2019). Flaxseeds have potential health benefits including reduction of blood cholesterol levels and the risk of cardiovascular diseases. Sensory evaluation of bread and cakes showed that partial replacement of wheat flour especially in the range of 5 to 10 per cent with flaxseed meal could be conducted without significant changes of organoleptic properties but with enhancement of fiber and protein contents (Khaled et al., 2019).

Preparation of cookies with partial replacement of the wheat flour with roasted or ground flaxseed showed that cookies with $15 \%$ level of substitution and below had acceptable evolution properties (Rajiv et al., 2012). Incorporation of red mombin (Spondias purpurea L.) seed flour into the chocolate brownies produced using wheat flour increased dietary fiber and ash contents, physical characteristics, and antioxidant activity allowing longer preservation of the product. It was shown that red mombin seed flour could completely replace wheat flour in chocolate brownies (de Abreu et al., 2021). Microencapsulated garden cress seed oil in whey protein concentrate with oil/protein ratio of 0.4 was used in biscuits preparation to replace flour and fat (Umesha et al., 2015). It was shown that annatto (Bixa Orellana L.) seeds powder served as a source of antioxidants to retard lipid and protein oxidation in pork patties during their storage at $4^{\circ} \mathrm{C}$ and displayed also antimicrobial activity (Cuong and Chin, 2016).

\section{Trend 6. By-products of plant processing for food preparation}

Many by-products of plant processing were proposed to be used as antioxidants in preparation of meat products (Aminzare et al., 2019). Half of the nitrite in the pork luncheon roll was replaced with $1.5 \%$ of tomato (Solanum lycopersicum) pulp powder. Rolls with reducing content of nitrite had higher acceptability. However, the addition of bigger amount of tomato pulp powder (3\%) affects the colour and texture of the rolls (Hayes et al., 2013). Extracts from tomato pomace used for spreading on lamb longissimus thoracis surface showed antioxidant activity and improved shelf-life of atmosphere-packaged meat (Andres 
et al., 2017). Quinoa paste was used at quantity 5\% for partially replacing fat in pork liver pate (Pellegrini et al., 2018). The addition of quinoa paste to pork liver pate retarded the lipid oxidation, increased emulsion stability, so stability of the product was increased. At the same time, the samples with quinoa pasta had higher fiber content and reduced content of fat, so the healthiness of the product was improved. The most acceptable sample was the pâté containing red quinoa at $5 \%$.

Addition of different plant materials to dough, mainly for replacement of animal fat to improve health properties of food products, was studied. However, application of hemicellulose- containing substances was also tried to be used for replacement of sugar or flour in bakeries. Ginger powder was proposed to be added (1\% and $2 \%)$ to rabbit burgers (Mancini et al., 2017). The results showed that this addition increased the content of polyunsaturated fatty acids omega- 3 and omega- 6 as well as antioxidant capacity of rabbit burgers while lipid peroxidation values were decreased. By-products, such pomaces or puree, from the fruit juice industry are characterized by high content of bioactive components and fiber. Addition of green banana puree in pound cakes for replacement of traditionally used butter were studied (de Souza et al., 2018). It was shown that replacing fat at $25 \%$ resulted in reduction of $20 \%$ and $40 \%$ of sugar in green banana puree low-fat cakes meanwhile sensory characteristics did not change significantly. It was shown that the sponge cakes cooked with black currant and aronia pomace for replacement of fat (30\% substitution) were well accepted by consumers, meanwhile partial replacement of sugar or flour decreased the quality of sponges (Quiles et al., 2018). Replacement of up to $50 \%$ of fat (butter) by avocado puree in muffins resulted in decrease of caloric value of low-fat muffins; meanwhile their organoleptic properties were acceptable (Othman et al., 2018). Okra gum was recommended to be used for replacement of fat (100\% substitution) in chocolate bar cookies (RomanchikCerpovicz et al., 2002).

\section{Trend 7. Replacement of gluten in bakery products}

In recent years, a lot of research was conducted to find the ways for replacement of gluten proteins in bakery products. Gluten proteins, mainly gliadins and glutenins, represent about $80 \%$ of the wheat flour protein and ensure the elastic and extensible properties of dough. However, it has been considered as a wheat grain allergen and about $1 \%$ of the world population is sensitive to gluten (Battais et al., 2008; Wang et al., 2017). So, there are a lot of propositions of the replacement of wheat flour with different gluten-free cereal flours to produce gluten-free bakery products (Peris et al., 2019). Among gluten-free cereal flours used for substitution of wheat flour there are rice flour (Bourekoua et al., 2016; Sciarini et al., 2010) corn flour (Bourekoua et al., 2016); sorghum flour (Marston et al., 2016; Rao et al., 2016), and combinations of mentioned above flours, for example, rice and soybean flours in ratio of 70 to 30 (de la Luz Guerrero-Elizarraraz, 2017), rice, corn and soy flours (Sciarini et al., 2010) and others.

There are also a lot of researches studying possibility or the replacement of wheat flour by flour of pseudo-cereals such as buckwheat (Fagopyrum esculentum and Fagopyrum tartaricum) (Jan et al., 2015; Sakac et al., 2015), legume flours (Cheng et al., 2016; de la Hera et al., 2012; Pasqualone et al., 2019a), quinoa (Chenpodium quinoa) (Watanabe et al., 2014), amaranth (Amaranthus sp.) (Chauhan et al., 2016) and their mixture (Buresova et al., 2017).

It is known that gluten is responsible for flour technological characteristics to make high quality bakery products. However, it was shown that combination of some flours with certain 
properties allowed to obtain gluten-free bread with good characteristics. Thus, gluten-free breads prepared with different combinations of rice, corn and soy flours differed significantly by their quality. It was established that bread made from a mixture of rice, corn and soy flours, taken in ratio of 40:40:20, had the best qualities characteristics such as high specific volume, good crumb appearance and soft texture (Sciarini et al., 2010) (Figure 2).
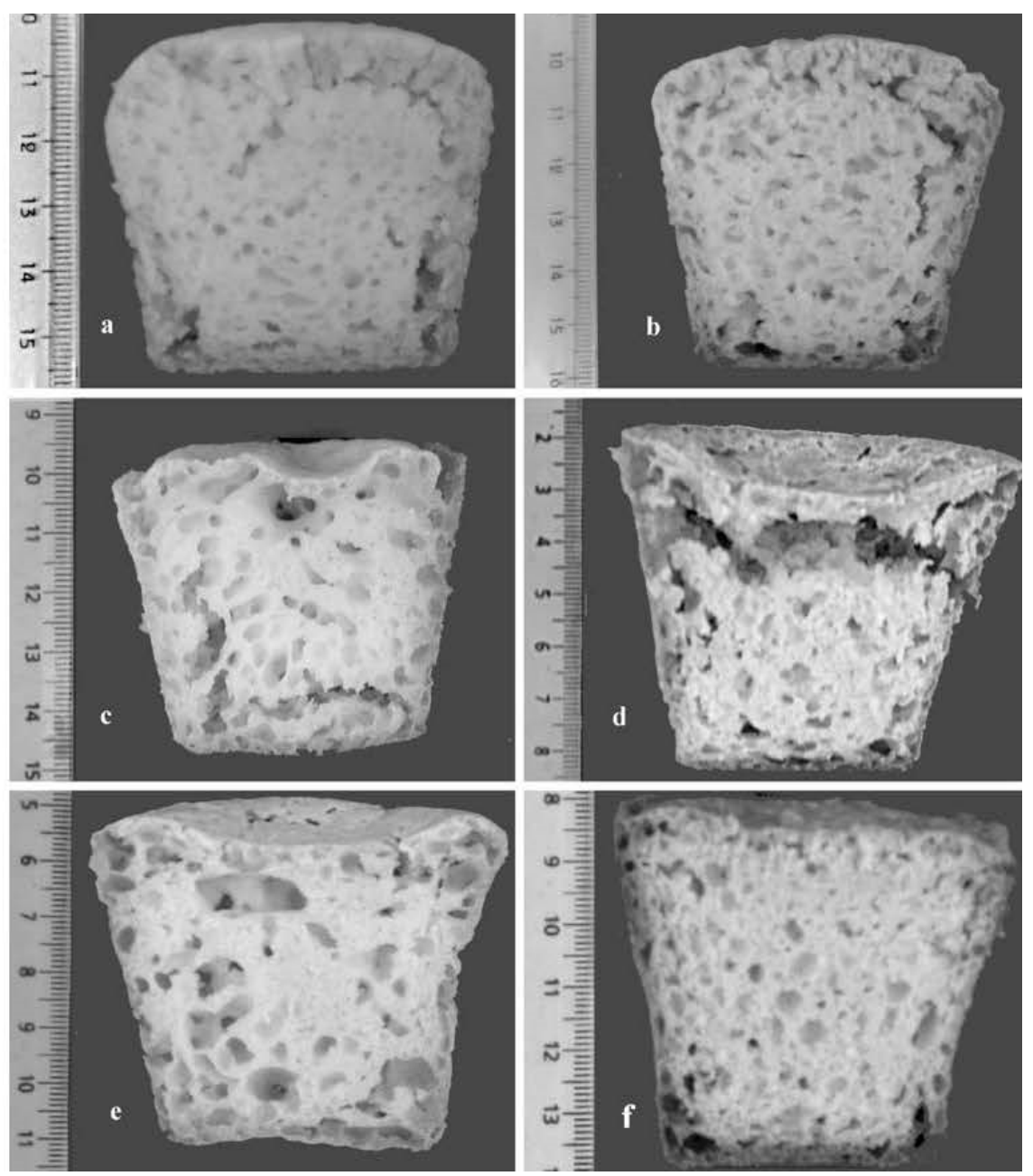

Figure 2. Images of gluten free bread slices: rice (a), rice/soy 90:10 (b), rice/corn 50:50 (c), corn/soy 80:20 (d), rice/corn/soy 45:45:10 (e), rice/corn/soy 40:40:20 (f) ((Sciarini et al., 2010).

Addition of quinoa (Chenopodium quinoa) flour to the cookies to substitute for $7.5 \%$ or $15 \%$ of wheat flour increased their antioxidant capacity, content of lysine and decreased the peroxide value (Watanabe et al., 2014). In spite of that, the addition of $15 \%$ of quinoa flour affected flavor and it was suggested that they were acceptable to the panelists. In another 
research, the cookies added with amaranth flour up to $60 \%$ showed good acceptability (Chauhan et al., 2016).

The mixture of gluten free flours of amaranth, buckwheat, chickpea, corn, millet and quinoa was blended with rice flour to compare their effect on technological parameters of bread production (Buresova et al., 2017). Addition of buckwheat flour (30 g/100 g; $50 \mathrm{~g} / 100$ $\mathrm{g}$ of rice flour) improved bread quality, meanwhile addition of amaranth, chickpea and quinoa flours affected the aroma and taste of breads, and addition of millet and corn flour deteriorated dough and bread quality.

Recently, a lot of research was done connected with usage of acorn flour in bread preparation. Acorn flour is rich in bioactive compounds, antioxidants and can be used as a gluten free material for bakery (Martins et al., 2020; Pasqualone et al., 2019b). Acorn flour added in the quantity of $23 \%$ and $35 \%$ of the flour mixture which consisted of buckwheat and rice flours showed good technological properties and its usage could improve bread nutritional and sensory characteristics (Martins et al., 2020).

\section{Trend 8. Seed oil in food production}

Application of a mix of grape seed oil $(0 \%, 5 \%, 10 \%$ and $15 \%)$ and $2 \%$ rice bran fiber was proposed for partially substituting the pork fat content in meat batter. The samples with increasing content of grape seed oil had not only reduced content of the animal fat, but were characterized with lower loss during cooking emulsion stability, and apparent viscosity (Choi et al., 2010).

Grape seed oil was also proposed to be used in preparation of meat emulsion. Grape seed oil emulsified in combination with gelatin and alginate was used for partial replacement of pork fat. This replacement improved the quality of meat emulsion and its health value (Kim et al., 2020). Grape seed oil demonstrated higher antioxidant activity than sunflower oil and olive oil. The addition of grape seed oil for $40 \%$ fat replacement in pork patties reduced the formation of heterocyclic amines during cooking without change of eating quality.

\section{Trend 9. Dietary fibers in food production}

Dietary fiber is the part of plant food that cannot be absorbed by humans and is resistant to enzymatic digestion in the human gastrointestinal tract (Yang et al., 2017). By their chemical structure dietary fibers with the exception of lignin are polysaccharides such as cellulose, hemicellulose, pectin, gums, and mucilage. All dietary fibers are divided in two groups: soluble (cellulose, hemicellulose and lignin) and dissolves in water to form gels (pectin, gums, and mucilage). The numerous studies were conducted to show positive influence of fiber intake and health benefit, mainly by the reduction of blood cholesterol, as well as improving of colonic function, and regulation of blood glucose (Dhingra et al., 2012).

Recommended daily intake of dietary fibre for adults in most countries is between 25 and $35 \mathrm{~g}$ (25-32 g/d for women and 30-35 g/d for men) and less for children and older adults (Stephen et al., 2017). Dietary fiber is recommended to be used in preparation of various functional foods like meat products, bakery, drinks, and beverages.

The addition of dietary fiber to meat products was proposed to increase their nutritional and healthy value as well as increase their acceptability and cooking yield (Talukder, 2015). A dietary fiber containing material recovered from the olive mill wastewater was proposed 
to be added to meatball to improve their cooking properties and reduce fat content (Galanakis et al., 2010). Sausage is a very popular meat product but the content of fat in it is too high. Partial substitution of fat in sausages with dietary fiber is recommended (Ham et al., 2016; Souza et al., 2019; Yang et al., 2010). Addition of hydrated oatmeal in quantity $10 \%$ for partial replacement of fat in sausages resulted in improving of technological parameters such as cooking yield and textural properties and an increasing of low-fat sausages acceptability (Yang et al., 2010). Low-fat beef sausages were prepared with addition of water to replace fat and pineapple fibre was added in quantity of $1 \%$ to bind additional water in sausage formulations. (Henning et al., 2016). The textural parameters of low-fat sausages were lower that of the control, however, addition of pineapple fiber in combination with water is considered as a way to reduce lipid content in sausages, increase the dietary fibre component and improve the health value of product (Henning et al., 2016).

The by-product from the production of red wine from Vitis vinifera grapes in the form of flour with a high content of dietary fiber (40\%) was used to replace 1,2 and $3 \%$ of bacon in salami preparation (Mendes et al., 2014). This addition resulted in a significant increase in the nutritional properties of the produced salami. Some studies are referred to usage of dietary fibre in preparation of meat emulsions to improve their quality. Makgeolli lees, byproduct of a production of traditional Korean rice and cereal wine, added as a source of dietary fiber to chicken meat emulsion system in quantity of $2 \%$, improved its stability and viscosity and decreased cooking loss (Choi et al., 2010a).

The addition of dietary fiber to bakery products is widely used to increase their nutritional value, improve their acceptability and extend the shelf-life. The addition of soluble fiber, which was partially hydrolyzed guar gum, $3.4 \mathrm{~g}$, and water, $36 \mathrm{~mL}$, in $100 \mathrm{~g}$ flour for noodles preparation had a significant positive effect on textual properties and increased the soluble fiber content to $3.6 \%$ as compared to $1.1 \%$ in control noodles (Mudgil et al., 2016).

Banana peel is a waste which is produced in a huge quality as a by-product of the food processing industry. Meanwhile, it is a rich source of dietary fibre $(43-50 \%)$, polyunsaturated fatty (linoleic $\alpha$-linolenic) acids and micronutrients (Mohapatra et al., 2016). Banana peel powder was proposed to be added to chapati dough up to 20\% (Kurhade et al., 2016). It was shown that addition of banana peel powder resulted in increase of dough stickiness and improved pliability. The substitution of wheat flour with $30 \%$ matured green banana flour increased total dietary fibre contents, content of minerals as well as antioxidant activity of noodles meanwhile the quality of noodle with banana flour was comparable to the control (Choo and Aziz, 2010). Stabilized rice bran flour with high content of dietary fiber (26\%) was added at level of 5\% to enrich the pizza dough (De Delahaye et al., 2005). The sensorial evolution showed acceptability of enriched pizza dough and ensured it stability during 60 days at $-18^{\circ} \mathrm{C}$.

Incorporation of food grade orange fiber extracted from orange juice by-product, consisted from peels and seeds, was tested as a fat-replacer at different percentages $(30,50$, and $70 \%$ ) in brioches, bakery confectionery products (Caggia et al., 2021). It was shown that brioches with $50 \%$ fat substitution had lower fat content, increased content of dietary fiber and improved technological properties.

New coffee by-products, silverskin extract, have been proposed to be used as a source of dietary fibre and bioactive compounds in preparation of developed novel food products (Figure 3) (Iriondo-DeHond et al., 2020). 


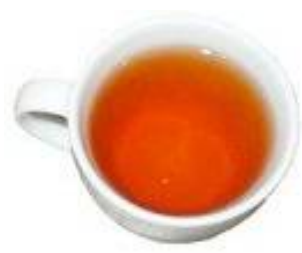

A

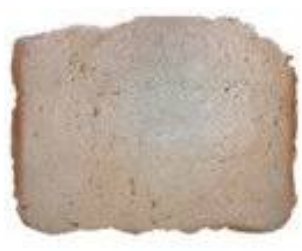

B

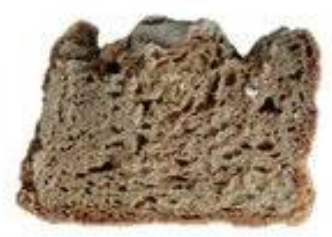

C

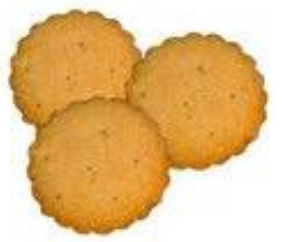

D

Figure 3. Products with coffee silverskin extract:

(A) beverages from Arabica and Robusta;

(B) wheat bread slice;

(C) gluten-free bread;

(D) biscuits

(Iriondo-DeHond et al., 2020).

There are some studies proposed additions of dietary fiber in dairy products, mainly in yogurts. Among the sources of fiber proposed to be added in yogurts there were oat fiber, wheat bran, pineapple and pina colada, fibers from apple, wheat, bamboo, asparagus, guar gum, orange fiber and date fibre (Hashim et al., 2009). It was shown that addition of fiber in yogurt may increase its health value, but can affect yogurt's technological characteristics and acceptability.

\section{Trend 10. Novel edible coatings materials of plant origins}

New trend in food production is an application of edible coating of different food product (fruits, vegetables, meat, fish, bakery, and snacks) to protect their quality, create a barrier against moisture lost and gas diffusion, prevent the loss of natural volatile flavour compounds and color components, delay enzymatic and microbial spoilage and extent shelf life (Sapper and Chiralt, 2018). Edible coating materials could be directly applied by spraying or dipping method over the food product to obtain a thin protective layer, but the preferred technique for edible coating is dipping. Materials for development of edible coating include polysaccharides such as starch, alginate, cellulose, chitosan, pectin, edible biopolymers pullulan and carrageenan, and plants gums; peptides such as gelatin, collagen, gluten, casein, and lipid-based materials, mainly different waxes (Suhag et al., 2020). Natural antioxidant and antimicrobial agents have also been incorporated in the edible film to increase the protection properties of food products and extend their shelf life.

Some examples of edible coating applications are shown below. Coating with $1 \%$ chitosan helped to maintain strawberries quality during storage (Yan et al., 2019). Arabic gum and almond gum were proposed to be used as novel edible materials for coating vegetables and fruits. The ripening process of semi-matured green tomatoes treated with aqueous solution of gum arabic, $1.5 \%$, was delayed during their storage at $32^{\circ} \mathrm{C}$ and $35-42 \%$ relative humidity for 28 days without changes in postharvest quality (Krishnadev, 2017). Coating of sweet cherries with $10 \%$ almond gum or arabic gum delayed their ripening during their storage at $2^{\circ} \mathrm{C}$ and $90-95 \%$ relative humidity for 15 days and extended the shelf life (Mahfoudhi and Hamdi, 2015). Coatings with the guar gum, $0.15 \%(\mathrm{~m} / \mathrm{v})$, added with calcium chloride, $0.1 \%(\mathrm{~m} / \mathrm{v})$, glycerol, $0.1 \%(\mathrm{~m} / \mathrm{v})$, and ginseng extract, $1 \%(\mathrm{~m} / \mathrm{v})$, helped 
to maintain the quality of sweet cherry and extend sweet cherries' shelf life during storage at $20^{\circ} \mathrm{C}$ and $70-75 \%$ relative humidity for about 8 days (Dong and Wang, 2018).

Edible films can be used as an alternative for prolongation of the shelf life of fish. Coating with gelatin-chitosan film incorporated with $4 \%$ of oregano essential oil was proposed for fish preservation (Wu et al., 2014). Biodegradable chitosan, 2\% (wt./vol.), coating incorporated with black pepper essential oil, 1.5\% (wt./vol.) was used for common carp fillet coating to extend its shelf life at refrigerated storage at $4^{\circ} \mathrm{C}$ (Moosavi-Nasab et al., 2016). Rosemary essential and extract oil, $2000 \mathrm{pm}$ and $200 \mathrm{ppm}$ by total phenol basis, respectively, were entrapped in carboxyl methyl cellulose to be used as edible coating for smoked eel (Choulitoudi et al., 2017). Application of this coating retarded oxidation processes in eel and showed antimicrobial activity against bacteria Pseudomonas spp. and lactic acid bacteria.

It was shown that coating reduced microbial load of the samples, improved fish fillet quality with the increasing of shelf life from 8 to 16 days. However, there is no data according acceptability of this coating fish. An edible gelatin films added with carvacrol, a monoterpenoid phenol presented in essential oils in many spices, was used to wrap of prefried breaded hake medallions (Neira et al., 2019). It was shown that the medallions wrapped in film can be cooked and consumed without removing the packaging and acceptance by the consumer was good.

Application of a new edible coating of pectin containing clove essential oil was proposed for treatment of bream fillets for extension of shelf life during refrigeration improved water holding capacity, color, and texture of the fillets, decreased weight loss, lipid oxidation, number of Gram-negative bacteria, meanwhile lactic acid bacteria were not affected (Nisar et al., 2019).

Dry fermented sausages were coated with chitosan added with essential oil of oregano for protection from lipid oxidation during seven months of storage. It was shown that coating sausages had better odor and flavor at the end of the experiment (Krkic et al., 2013). Biodegradable film contained gelatin and incorporated in it $7.5 \%$ microparticles of powder papaya peel as natural antioxidant was used as packaging material for lard. It was shown that this packing material was effective as active barrier with high antioxidant activity and was recommended as environmentally friendly packaging of fat products (de Moraes Crizel et al., 2018).

Coating of potato chips was conducted using almond gum concentration $20 \mathrm{~g} / \mathrm{L}, 75 \mathrm{~s}$ frying time at $160{ }^{\circ} \mathrm{C}$ frying temperature (Bouaziz et al., 2016). It was shown that coating decreased the oil uptake of potato chips by $34 \%$ and improved their sensorial qualities such as color, appearance, crispiness, taste, odor which resulted in chip's better acceptability.

It was strongly recommended to incorporate berries into edible films. Thus, blackberries particles with high content of anthocyanin incorporated in arrowroot starch ensured the presence of bioactive compounds and antioxidant capacity of protective film (Nogueira et al., 2019).

\section{Conclusions}

Application of novel natural additives, such as plants with pharmaceutical properties, plant materials with antioxidant activity, essential plants oils, extracts from plant materials seaweeds, seeds products, different gluten-free cereal and pseudo-cereals flours for replacement of gluten in bakery products, dietary fibers, edible coatings materials of plant origins, in preparation of different food products is widely studied in recent 10 years. The 


\section{- Food Technology -}

main object of these researches is improving the health value of traditional products, saving or improving their quality and acceptability by consumers as well as an extension of shelf life.

Despite evident beneficial effects, careful examination of new products should be done in every case to establish an optimal dosage of additives, to prove its safety and evaluation of possible side effects on human health.

\section{References}

de Abreu D.J.M., de Moraes I.A., Asquieri E.R., Damiani C. (2021), Red mombin (Spondias purpurea L.) seed flour as a functional component in chocolate brownies. Journal of Food Science and Technology, 58, pp. 612-620, DOI: 10.1007/s13197-020-04574-4.

Alshehry G.A. (2020), Preparation and nutritional properties of cookies from the partial replacement of wheat flour using pumpkin seeds powder, World Journal of Environmental Biosciences, 9(2), pp. 48-56.

de Almeida P.L., de Lima S.N., Costa L.L., de Oliveira C.C., Damasceno K.A., dos Santos B.A., Campagnol P.C. (2015), Effect of jabuticaba peel extract on lipid oxidation, microbial stability and sensory properties of Bologna-type sausages during refrigerated storage, Meat Science, 110, pp. 9-14, DOI: 10.1016/j.meatsci.2015.06.012.

Aminzare M., Aliakbarlu J., Tajik H. (2015), The effect of Cinnamomum zeylanicum essential oil on chemical characteristics of Lyoner-type sausage during refrigerated storage, Veterinary Research Forum, 6(1), pp. 31-39.

Aminzare M., Tajik H., Aliakbarlu J., Hashemi M., Raeisi M. (2018), Effect of cinnamon essential oil and grape seed extract as functional-natural additives in the production of cooked sausage-impact on microbiological, physicochemical, lipid oxidation and sensory aspects, and fate of inoculated Clostridium perfringen, Journal of Food Safety, 38, e12459, DOI: $10.1111 / \mathrm{jfs} .12459$.

Aminzare M., Hashemi M., Ansarian E., Bimkar M., Azar H.H., Mehrasbi M.R., Daneshamooz S., Raeisi M., Jannat B., Afshari A. (2019), Using natural antioxidants in meat and meat products as preservatives: A review, Advances in Animal and Veterinary Sciences, 7(5), pp. 417-426, DOI: 10.17582/journal.aavs/2019/7.5.417.426.

Andres A.I., Petron M.J., Delgado-Adamez J., Lopez M., Timon M. (2017), Effect of tomato pomace extracts on the shelf-life of modified atmosphere-packaged lamb meat. Journal of Food Processing and Preservation, 41(4), Article e13018, DOI: 10.1111/jfpp.13018

ANS (2012) Guidance for submission for food additive evaluations, EFSA Panel on Food Additives and Nutrient Sources added to Food (ANS) European Food Safety Authority $\begin{array}{lllll}\text { (EFSA), } \quad \text { Parma, } & \text { Italy. }\end{array}$ https://efsa.onlinelibrary.wiley.com/doi/pdfdirect/10.2903/j.efsa.2012.2760

Antonini E., Torri L., Piochi M., Cabrino G., Assunta M. (2020), Nutritional, antioxidant and sensory properties of functional beef burgers formulated with chia seeds and goji puree, before and after in vitro digestion, Meat Science, 161, Article 108021, DOI: 10.1016/j.meatsci.2019.108021.

Arufe S., Della Valle G., Chiron H., Chenlo F., Sineiro J., Moreira R. (2018), Effect of brown seaweed powder on physical and textural properties of wheat bread, European Food Research and Technology, 244, pp. 1-10, DOI: 10.1007/s00217-017-2929-8.

Aumeeruddy-Elalfi Z., Gurib-Fakim A., Mahomoodally F. (2015), Antimicrobial, antibiotic potentiating activity and phytochemical profile of essential oils from exotic and endemic medicinal plants of Mauritius, Industrial Crops and Products, 71, pp.197-204, DOI: 10.1016/j.indcrop.2015.03.058. 
Bajera T., Silha D., Ventura K., Bajerov P. (2017), Composition and antimicrobial activity of the essential oil, distilled aromatic water and herbal infusion from Epilobium parviflorum Schreb, Industrial Crops and Products, 100, pp. 95-105, DOI: 10.1016/j.indcrop.2017.02.016.

Batista J.E.R., Braga, L.P., Oliveira R.C., de Silva E.P., Damiani C. (2018), Partial replacement of wheat flour by pumpkin seed flour in the production of cupcakes filled with carob, Food Science and Technology, 38(2), pp. 250-254, DOI: 10.1590/1678-457x.36116.

Battais F., Richard C., Jacquenet S., Denery-Papini S., Moneret-Vautrin D.A. (2008), Wheat grain allergies: An update on wheat allergens, European Annals of Allergy and Clinical Immunology, 40(3), pp. 67-76. http://www.eurannallergyimm.com/cont/journalsarticles/122/volume-wheat-grain-allergies-update-allergens-321allasp1.pdf

Bellucci E.R.B., Munekata P.E.S., Pateiro M., Lorenzo J.M., da Silva B.A.C. (2021), Red pitaya extract as natural antioxidant in pork patties with total replacement of animal fat, Meat Science, 171, 108284, DOI: 10.1016/j.meatsci.2020.108284.

Bolarinwa I.F., Aruna T.E., Raji A.O. (2019), Nutritive value and acceptability of bread fortified with moringa seed powder, Journal of the Saudi Society of Agricultural Sciences, 18(2), pp. 195-200, DOI: 10.1016/j.jssas.2017.05.002.

Bora P., Ragaeea S., Abdel-Aal E.S.M. (2019), Effect of incorporation of goji berry by-product on biochemical, physical and sensory properties of selected bakery products, $L W T-$ Food Science and Technology, 112, Article 108225, DOI: 10.1016/j.lwt.2019.05.123.

Bouaziz F., Koubaa M., Neifar M. et al. (2016), Feasibility of using almond gum as coating agent to improve the quality of fried potato chips: evaluation of sensorial properties, $L W T-F o o d$ Science and Technology, 65, pp. 800-807, DOI: 10.1016/j.lwt.2015.09.009.

Bourekoua H., Benatallah L., Zidoune M.N., Rosell C.M. (2016), Developing gluten free bakery improvers by hydrothermal treatment of rice and corn flours, LWT-Food Science and Technology, 73, pp. 342-350, DOI: 10.1016/j.lwt.2016.06.032.

Brnawi W.I., Hettiarachchy N.S., Horax R., Kumar-Phillips G., Seo H.S., Marcy J. (2018), Comparison of cinnamon essential oils from leaf and bark with respect to antimicrobial activity and sensory acceptability in strawberry shake, Journal of Food Science, 83(2), pp. 475-480, DOI: 10.1111/1750-3841.14041.

Brownlee I., Fairclough A., Hall A., Paxman J. (2012), The potential health benefits of seaweed and seaweed extract, In: Seaweed: Ecology, Nutrient Composition and Medicinal Uses. Marine Biology: Earth Sciences in the 21st Century (Pomin V.H., ed.), Nova Science Publishers: Hauppauge, NY, USA, pp. 119-136.

Buresova I., Tokar M., Marecek J., Hrivna L., Famera O., Sottnikova V. (2017), The comparison of the effect of added amaranth, buckwheat, chickpea, corn, millet and quinoa flour on rice dough rheological characteristics, textural and sensory quality of bread, Journal of Cereal Science, 75, pp. 158-164, DOI: 10.1016/j.jcs.2017.04.004.

Caggia C., Palmeri R., Russo N., Timpone R., Randazzo C.L., Todaro A., Barbagallo S. (2020), Employ of citrus by-product as fat replacer ingredient for bakery confectionery products, Frontiers in Nutrition, 7, p. 46, DOI: 10.3389/fnut.2020.00046.

Caleja C., Ribeiro A., Barros L., Barreira J.C., Antonio A.L., Oliveira M.B.P., Barreiro M.F., Ferreira I.C. (2016), Cottage cheeses functionalized with fennel and chamomile extracts: Comparative performance between free and microencapsulated forms. Food Chemistry, 199(15), pp. 720-726, DOI: 10.1016/j.foodchem.2015.12.085

Caleja C., Barros, L., Antonio A.L., Oliveira M.B.P., Ferreira I.C. (2017), A comparative study between natural and synthetic antioxidants: Evaluation of their performance after incorporation into biscuits, Food Chemistry, 216, pp. 342-346, DOI: 10.1016/j.foodchem.2016.08.075 


\section{- Food Technology -}

Cardoso S.M., Carvalho L.G., Silva P.J., Rodrigues M.S., Pereira O.R., Pereira L. (2014), Bioproducts from seaweeds: A review with special focus on the Iberian Peninsula, Current Organic Chemistry, 18(7), pp. 896-917, DOI: 10.2174/1385272818071405151541

Cardoso S.M., Pereira O.R., Seca A.M.L., Pinto D.C.G.A., Silva A.M.S. (2015), Seaweeds as preventive agents for cardiovascular diseases: from nutrients to functional foods, Marine Drugs, 13(11), pp. 6838-6865, DOI: 10.3390/md13116838.

de Carvalho F.A.L., Lorenzo J.M., Pateiro M., Bermudez R., Purrinos L., Trindade M.A. (2019), Effect of guarana (Paullinia cupana) seed and pitanga (Eugenia uniflora L.) leaf extracts on lamb burgers with fat replacement by chia oil emulsion during shelf life storage at $2{ }^{\circ} \mathrm{C}$, Food Research International, 125, 108554, DOI: org/10.1016/j.foodres.2019.108554.

Castro-Lopez C., Ventura-Sobrevilla J.M., Gonzalez-Hernandez M.D., Rojas R., Ascacio-Valdes J.A., Aguilar C.N., Martínez-Avila G.C. (2017), Impact of extraction techniques on antioxidant capacities and phytochemical composition of polyphenol-rich extracts, Food Chemistry, 237, pp. 1139-1148, DOI: 10.1016/j.foodchem.2017.06.032.

Chauhan A., Saxena D.C., Singh S. (2016), Physical, textural, and sensory characteristics of wheat and amaranth flour blend cookies, Cogent Food \& Agriculture, 2(1), Article: 1125773. DOI: 10.1080/23311932.2015.1125773.

Cheng Y.F., Bhat R. (2016), Functional, physicochemical and sensory properties of novel cookies produced by utilizing underutilized jering (Pithecellobium jiringa Jack.) legume flour, Food Bioscience, 14, pp. 54-61, DOI: 10.1016/j.fbio.2016.03.002.

Cherry P., O'Hara C., Magee P.J., McSorley E.M., Allsopp P.J. (2019), Risks and benefits of consuming edible seaweeds, Nutrition Reviews, 77(5), pp. 307-329.

Chizoba N.N. (2014), Sensory evaluation of cookies produced from different blends of wheat and Moringa oleifera leaf flour, International Journal of Nutrition and Food Sciences, 3, 307, DOI: 10.1093/nutrit/nuy066.

Choi Y.S., Choi J.H., Han D.J., Kim H.Y., Lee M.A., Kim H.W., Lee J.W., Chung H.J., Kim C.J. (2010), Optimization of replacing pork back fat with grape seed oil and rice bran fiber for reduced-fat meat emulsion systems, Meat Science, 84(1), pp. 212-218, DOI: 10.1016/j.meatsci.2009.08.048.

Choi Y.S., Park K.S., Choi J.H., Kim H.W., Song D.H., Kim J.M., Chung H.J., Kim C.J. (2010a), Physico-chemical properties of chicken meat emulsion systems with dietary fiber extracted from Makgeolli Lees, Korean Journal for Food Science of Animal Resources, 30(6), pp. 910-917. https://www.koreascience.or.kr/article/JAKO201013351020017.pdf.

Choi Y.S., Choi J.H., Han D.J., Kim H.Y., Kim H.W., Lee M.A., Chung H.J., Kim C.J. (2012), Effects of Laminaria japonica on the physico-chemical and sensory characteristics of reduced-fat pork patties, Meat Science, 91(1), pp. 1-7, DOI: 10.1016/j.meatsci.2011.11.011.

Choi Y.S., Kim H.W., Hwang K.E., Song D.H., Choi J.H., Lee M.A., Chung H.J., Kim C.J. (2014), Physicochemical properties and sensory characteristics of reduced-fat frankfurters with pork back fat replaced by dietary fiber extracted from makgeolli lees, Meat Science, 96(2), Part A, pp. 892-900, DOI: 10.1016/j.meatsci.2013.08.033.

Choo C.L., Aziz N.A.A. (2010), Effects of banana flour and $\beta$-glucan on the nutritional and sensory evaluation of noodles, Food Chemistry, 119(1), pp. 34-40, DOI: 10.1016/j.foodchem.2009.05.004.

Choulitoudi E., Ganiari S., Tsironi T., Ntzimani A., Tsimogiannis D., Taoukis P., Oreopoulou V. (2017), Edible coating enriched with rosemary extracts to enhance oxidative and microbial stability of smoked eel fillets, Food Packaging and Shelf Life, 12, pp. 107-113, DOI: 10.1016/j.fps1.2017.04.009.

Circuncisao A.R., Catarino M.D., Cardoso S.M., Silva A.M.S. (2018), Minerals from macroalgae origin: Health benefits and risks for consumers, Marine Drugs, 16(11), p. 400, DOI: $10.3390 / \mathrm{md} 16110400$. 
Coelho M.S., de Salas-Mellado M. (2015), Effects of substituting chia (Salvia hispanica L.) flour or seeds for wheat flour on the quality of the bread, LWT-Food Science and Technology, 60(2), pp. 729-736, DOI: 10.1016/j.lwt.2014.10.033.

Cofrades S., Benedi J., Garcimartin A., Sanchez-Muniz F.J., Jimenez-Colmenero F. (2017), A comprehensive approach to formulation of seaweed-enriched meat products: From technological development to assessment of healthy properties, Food Research International, 99, Part 3, pp. 1084-1094, DOI: 10.1016/j.foodres.2016.06.029.

Cuong T.V., Chin K.B. (2016), Effects of annatto (Bixa Orellana L.) seeds powder on physicochemical properties, antioxidant and antimicrobial activities of pork patties during refrigerated storage, Food Science of Animal Resources, 36, pp. 476-486, DOI: 10.5851/kosfa.2016.36.4.476.

De Delahaye E.P., Jimenez P., Perez E. (2005), Effect of enrichment with high content dietary fiber stabilized rice bran flour on chemical and functional properties of storage frozen pizzas, Journal of Food Engineering, 68(1), pp. 1-7, DOI: 10.1016/j.jfoodeng.2004.05.048.

Dhingra D., Michael M., Rajput H., Patil R.T. (2012), Dietary fibre in foods: a review, Journal of Food Science and Technology, 49(3), pp. 255-266, DOI: 10.1007/s13197-011-0365-5.

Devisetti R., Sreerama Y.N., Bhattacharya S. (2015), Processing effects on bioactive components and functional properties of moringa leaves: Development of a snack and quality evaluation, Journal of Food Science and Technology, 53(1), pp. 649-657, DOI: 10.1007/s13197-015-1962-5.

Dong F., Wang X. (2018), Guar gum and ginseng extract coatings maintain the quality of sweet cherry, LWT - Food Science and Technology, 89, pp. 117-122, DOI: 10.1016/j.lwt.2017.10.035.

Galanakis C., Tornberg E., Gekas V. (2010), Dietary fiber suspensions from olive mill wastewater as potential fat replacements in meatballs, LWT-Food Science and Technology, 43(7), pp. 1018-1025, DOI: 10.1016/j.lwt.2009.09.011.

Garcia-Diez J., Alheiro J., Pinto A.L., Soares L., Falco V., Fraqueza, M.J., Patarata L. (2017), Influence of food characteristics and food additives on the antimicrobial effect of garlic and oregano essential oils, Foods, 6(6), 44, DOI: 10.3390/foods6060044.

Gokoglu N. (2019), Novel natural food preservatives and applications in seafood preservation: a review, Journal of the Science of Food and Agriculture, 99(5), pp. 2068-2077, DOI: $10.1002 /$ jsfa. 9416.

Gouvea F.S., Rosenthal A., Ferreira E.H.R. (2017), Plant extract and essential oils added as antimicrobials to cheeses: a review, Ciencia Rural, 47(8), DOI: 10.1590/0103$8478 \mathrm{cr} 20160908$.

El-Soukkary F. (2001), Evaluation of pumpkin seed products for bread fortification, Plant Foods for Human Nutrition, 56, pp. 365-384, DOI: 10.1023/A:1011802014770.

Fernandes S.S., Salas-Mellado M.M. (2017), Addition of chia seed mucilage for reduction of fat content in bread and cakes, Food Chemistry, 227, pp. 237-244, DOI: 10.1016/j.foodchem.2017.01.075.

Fernandez-Lopez J., Sevilla L., Sayas-Barbera E., Navarro C., Marin F., Perez-Alvarez J. (2003), Evaluation of the antioxidant potential of hyssop (Hyssopus officinalis L.) and rosemary (Rosmarinus officinalis L.) extracts in cooked pork meat, Journal of Food Science, 68, pp. 660-664, DOI: 10.1111/j.1365-2621.2003.tb05727.x.

Ferreira J.M.M., Azevedo B.M., Luccas V., Bolini H.M.A. (2017), Sensory profile and consumer acceptability of prebiotic white chocolate with sucrose substitutes and the addition of goji berry (Lycium barbarum). Journal of Food Science, 82(3), pp. 818-824, DOI: 10.1111/1750-3841.13632. 
Fitzgerald C., Gallagher E., Tasdemir D., Hayes M. (2011), Heart health peptides from macroalgae and their potential use in functional foods, Journal of Agricultural and Food Chemistry, 59(13), pp. 6829-6836, DOI: 10.1021/jf201114d.

Hall A.C., Fairclough A.C., Mahadevan K., Paxman J.R. (2012), Ascophyllum nodosum enriched bread reduces subsequent energy intake with no effect on post-prandial glucose and cholesterol in healthy, overweight males. A pilot study, Appetite, 58(1), 379-386, DOI: 10.1016/j.appet.2011.11.002.

Ham Y.K., Hwang K.E., Kim H.W., Song D.H., Kim Y.J., Choi Y.S., Kim C.J. (2016), Effects of fat replacement with a mixture of collagen and dietary fibre on small calibre fermented sausages, International Journal of Food Science and Technology, 51(1), pp. 96-104, DOI: 10.1111/ijfs. 12960 .

Hashim I.B., Khalil A.H., Afifi H.S. (2009), Quality characteristics and consumer acceptance of yogurt fortified with date fiber, Journal of Dairy Science, 92(11), pp. 5403-5407, DOI: $10.3168 /$ jds.2009-2234.

Hassoun A., Coban O.E. (2017), Essential oils for antimicrobial and antioxidant applications in fish and other seafood products, Trends in Food Science \& Technology, 68, pp. 26-36, DOI: 10.1016/j.tifs.2017.07.016.

Hayes J.E., Canonico I., Allen P. (2013), Effects of organic tomato pulp powder and nitrite level on the physicochemical, textural and sensory properties of pork luncheon roll. Meat Science, 95(3), pp. 755-762, DOI: 10.1016/j.meatsci.2013.04.049.

Heck R.T., Lucas B.N., Santos D.J.P.D., Pinton M.B., Fagundes M.B., de Araujo Etchepare M., Cichoski A.J., de Menezes C.R., Barin J.S., Wagner R., Campagnol P.C.B. (2018), Oxidative stability of burgers containing chia oil microparticles enriched with rosemary by green-extraction techniques, Meat Science, 146, pp. 147-153, DOI: 10.1016/j.meatsci.2018.08.009.

Henning S.S.C., Tshalibe P., Hoffman L.C. (2016), Physico-chemical properties of reduced-fat beef species sausage with pork back fat replaced by pineapple dietary fibres and water, LWT-Food Science and Technology, 74, pp. 92-98, DOI: 10.1016/j.lwt.2016.07.007.

de la Hera E., Ruiz-París E., Oliete B., Gomez M. (2012), Studies of the quality of cakes made with wheat-lentil composite flours, LWT-Food Science and Technology, 49, pp. 48-54, DOI: 10.1016/j.lwt.2012.05.009.

Hrncic M.K., Ivanovski M., Cör D., Knez Z. (2020), Chia seeds (Salvia hispanica L.): An overview - phytochemical profile, isolation methods, and application, Molecules, 25(1), 11, DOI: 10.3390/molecules25010011.

Hwang K.E., Kim H.W., Song D.H., Kim Y.J., Ham Y.K., Choi Y.S., Lee M.A., Kim C.J. (2017), Effect of Mugwort and Rosemary either singly, or combination with ascorbic acid on shelf stability of pork patties, Journal of Food Processing and Preservation, 41(4), e12994, DOI: 10.1111/jfpp.12994.

Hyldgaard M., Mygind T., Meyer R.L. (2012), Essential oils in food preservation: mode of action, synergies, and interactions with food matrix components, Frontiers of Microbiology, 25(3), 12, DOI: 10.3389/fmicb.2012.00012.

Iriondo-DeHond A., Iriondo-DeHond M., del Castillo M.D. (2020), Applications of compounds from coffee processing by-products, Biomolecules, 10(9), 1219, DOI: 10.3390/biom 10091219 .

Jan U., Gani A., Ahmad M., Shah U., Baba W.N., Masoodi F.A. (2015), Characterization of cookies made from wheat flour blended with buckwheat flour and effect on antioxidant properties, Journal of Food Science and Technology, 52(10), pp. 6334-6344, DOI: 10.1007/s13197-015-1773-8.

Jiang Y., Fang Z., Leonard W., Zhang P. (2021), Phenolic compounds in Lycium berry: Composition, health benefits and industrial applications, Journal of Functional Foods, 77, Article 104340, DOI: 10.1016/j.jff.2020.104340. 
Ju J., Xie Y., Guo Y., Cheng Y., Qian H., Yao W. (2020), Application of starch microcapsules containing essential oil in food preservation, Critical Reviews in Food Science and Nutrition, 60(17), pp. 2825-2836, DOI: 10.1080/10408398.2018.1503590.

Kolawole F., Balogun M., Opaleke D., Amali H. (2013), An evaluation of nutritional and sensory qualities of wheat-moringa cake, Agrosearch, 13(1), DOI: 10.4314/agrosh.v13i1.9.

Khaled A.H.S., Mostafa K.M., Awad A.T.M., Rasha A.A. (2019), Effect of bioactive compounds of defatted flaxseed meal on rheological and sensorial properties of toast and cake, Journal of Food Science \& Technology, 4(4), pp. 707-719, DOI: 10.25177/JFST.4.4.RA.479.

Kim K.S. (2008), Beverage composition using sea weed Fusiforme and onion for the prevention $\begin{array}{llll}\text { of } & \text { WO } & 2008032958 & \text { A1. }\end{array}$ https://patentscope.wipo.int/search/en/detail.jsf?docId=WO2008032958.

Kim H.W., Choi J.H., Choi Y.S., Han D.J.;, Kim H.Y., Lee M.A., Kim S.Y., Kim C.J. (2010), Effects of sea tangle (Lamina japonica) powder on quality characteristics of breakfast sausages, Korean Journal of Food Science of Animal Resources, 3(1), pp. 55-61, DOI: 10.5851/kosfa.2010.30.1.55.

Kilınc B., Cirik S., Turan G., Tekogul H., Koru E. (2013), Seaweeds for food and industrial applications, In: Food Industry (Muzzalupo I., ed.), Intech, ISBN, pp. 735-748.

Kim T.K., Yong H.I., Jung S., Kim Y.B., Choia Y.S. (2020), Effects of replacing pork fat with grape seed oil and gelatine/alginate for meat emulsions, Meat Science, 163, 108079, DOI: 10.1016/j.meatsci.2020.108079.

Kobus-Cisowska J., Flaczyk E., Rudzinska M., Kmiecik D. (2014), Antioxidant properties of extracts from Ginkgo biloba leaves in meat balls, Meat Science, 97(2), pp. 174-180, DOI: 10.1016/j.meatsci.2014.01.011.

Krishnadev P. (2017), Development of gum arabic edible coating formulation through nanotechnological approaches and their effect on physico-chemical change in tomato (Solanum lycopersicum L) fruit during storage, International Journal of Agriculture Sciences, 9(8), pp. 3866-3870. http://www.bioinfopublication.org/jouarchive.php?opt=\&jouid=BPJ0000217.

Krkic N., Sojic B., Lazic V., Petrovic L., Mandic A., Sedej I., Tomovic V. (2013), Lipid oxidative changes in chitosan oregano coated traditional dry fermented sausage Petrovska klobasa. Meat Science, 93(3), pp. 767-770, DOI: 10.1016/j.meatsci.2012.11.043.

Kryzhova Y., Antonuk M., Stabnikov V., Stabnikova O. (2021), Application of seaweeds for enhancement of functional meat products with organic compounds of selenium and iodine, Ukrainian Food Journal, 10(1), pp. 136-144.

Kulczynski B., Kobus-Cisowska J., Taczanowski M., Kmiecik D., Gramza-Michałowska A. (2019), The chemical composition and nutritional value of chia seeds-current state of knowledge, Nutrients, 11(6), pp. 1242, DOI: 10.3390/nu11061242.

Kumar Y., Kumar V. (2020), Effects of double emulsion (W1/O/W2) containing encapsulated Murraya koenigii berries extract on quality characteristics of reduced-fat meat batter with high oxidative stability, LWT - Food Science and Technology, 127, 109365, DOI: 10.1016/j.lwt.2020.109365.

Kurhade A., Patil S., Sonawane S.K., Waghmare J.S., Arya S.S. (2016), Effect of banana peel powder on bioactive constituents and microstructural quality of chapatti: unleavened Indian flat bread, Journal of Food Measurement and Characterization, 10(1), pp. 32-41, DOI: 10.1007/s11694-015-9273-0.

Li N., Zhang Z.J., Li X.J., Li H.Z., Cui L.X., He D.L. (2018), Microcapsules biologically prepared using Perilla frutescens (L.) Britt. essential oil and their use for extension of fruit shelf life, Journal of the Science of Food and Agriculture, 98(3), pp. 1033-1041, DOI: $10.1002 /$ jsfa. 8552 .

Lim H.S., Kim H.H. (2013), Effects of the sea tangle-added patty on postprandial blood glucose and lipid profiles in borderline-hyperlipidemic adults, Federation of American Societies 
for Experimental Biology Journal, 27(S1), p. 1079.22, DOI: 10.1096/fasebj.27.1_supplement.1079.22.

Lordan S., Ross R.P., Stanton C. (2011), Marine bioactives as functional food ingredients: Potential to reduce the incidence of chronic diseases, Marine Drugs, 9(6), pp. 1056-1100, DOI: $10.3390 / \mathrm{md} 9061056$.

Lourenço S.C., Moldao-Martins M., Alves V.D. (2019), Antioxidants of natural plant origins: From sources to food industry applications, Molecules, 24(22), 4132, DOI: 10.3390/molecules24224132.

Lorenzo J.M., Pateiro M., Domínguez R., Barba F.J., Putnik P., Kovačević D.B., Shpigelman A., Granato D., Franco D. (2018), Berries extracts as natural antioxidants in meat products: A review. Food Research International, 106, pp. 1095-1104, DOI: 10.1016/j.foodres.2017.12.005

Lu F., Kuhnle G.K., Cheng Q. (2017), Vegetable oil as fat replacer inhibits formation of heterocyclic amines and polycyclic aromatic hydrocarbons in reduced fat pork patties, Food Control, 81, pp. 113-125, DOI: 10.1016/j.foodcont.2017.05.043.

Luciano C.G., Vargas F.C., Tessaro M., Trindade M.A., Arantes-Pereira L., Fernandes A.M., Sobral P.J.A. (2021), Pitangueira Leaf Extracts as Alternative to Traditional Additives in Fresh Pork Sausage. In: Cortez Vieira M.M., Pastrana L., Aguilera J. (eds) Sustainable Innovation in Food Product Design, Food Engineering Series, pp. 3-23, Springer, Cham, DOI: 10.1007/978-3-030-61817-9_1

de la Luz Guerrero-Elizarraraz M., Mares-Mares E., Sosa-Morales M.E. (2017), Physicochemical, sensory and nutritional evaluation of gluten-free bread based on rice and soybean flour, American Society of Agricultural and Biological Engineers, Annual International Meeting, 1700982, DOI: 10.13031/aim.201700982.

Ma Z.F., Zhang H., Teh S.S., Wang C.W., Zhang Y., Hayford F., Wang L., Ma T., Dong Z., Zhang Y., Zhu Y. (2019), Goji berries as a potential natural antioxidant medicine: An insight into their molecular mechanisms of action, Oxidative Medicine and Cellular Longevity, 2019, Article 2437397, DOI: 10.1155/2019/2437397.

Mahfoudhi N., Hamdi S. (2015), Use of almond gum and gum arabic as novel edible coating to delay postharvest ripening and to maintain sweet cherry (Prunus avium) quality during storage, Journal of Food Processing and Preservation, 39(6), pp. 1499-1508, DOI: $10.1111 /$ jfpp. 12369.

Mali S.S., Dhumal R.L., Havaldar V.D., Shinde S.S., Jadhav N.Y., Gaikwad B.S. (2020), A systematic review on Aegle marmelos (Bael), Research Journal of Pharmacognosy and Phytochemistry, 12(1), pp. 31-36, DOI: 10.5958/0975-4385.2020.00007.2.

Mamat H., Matanjun P., Ibrahim S. et al. (2014), The effect of seaweed composite flour on the textural properties of dough and bread, Journal of Applied Phycology, 26(2), pp. 10571062, DOI: $10.1007 / \mathrm{s} 10811-013-0082-8$.

Manaois R., Morales A., Abilgos-ramos R. (2013), Acceptability, shelf life and nutritional quality of Moringa-supplemented rice crackers, Philippine Journal of Crop Science, 38(2), pp. 18.

Maqsood S., Benjakul S., Shahidi F. (2013), Emerging role of phenolic compounds as natural food additives in fish and fish products, Critical Reviews in Food Science and Nutrition, 53(2), pp. 162-179, DOI: 10.1080/10408398.2010.518775.

Mancini S., Preziuso G., Dal Bosco A., Roscini V., Parisi G., Paci G. (2017), Modifications of fatty acids profile, lipid peroxidation and antioxidant capacity in raw and cooked rabbit burgers added with ginger, Meat Science, 133, 151-158, DOI: 10.1016/j.meatsci.2017.07.003.

Marquez-Rodríguez A.S., Nevarez-Baca S., Lerma-Hernandez J.C., Hernandez-Ochoa L.R., Nevarez-Moorillon G.V., Gutierrez-Mendez N., Munoz-Castellanos L.N., Salas E. (2020), 
In vitro antibacterial activity of Hibiscus sabdariffa L. Phenolic extract and its in situ application on shelf-life of beef meat, Foods, 9(8), 1080, DOI: 10.3390/foods9081080.

Marston K., Khouryieh H., Aramouni F. (2016), Effect of heat treatment of sorghum flour on the functional properties of gluten-free bread and cake, LWT-Food Science and Technology, 65, 637-644, DOI: 10.1016/j.lwt.2015.08.063.

Martins R.B., Gouvinhas I., Nunes M.C., Peres J.A., Raymundo A., Barros A. I.R.N.A. (2020), Acorn flour as a source of bioactive compounds in gluten-free bread, Molecules, 25(16), 3568, DOI: 10.3390/molecules2516356.

Mendes A.C.G., Rettore D.M., Ramos A.D.L.S., da Cunha S.D.F.V., de Oliveira L.C., Ramos E.M. (2014), Milano type salami elaborated with fibers of red wine byproducts, Rural Science, 44(7), pp. 1291-1296, DOI: 10.1590/0103-8478cr20130389.

Mesias M., Holgado F., Marquez-Ruiz G., Morales F.J. (2016), Risk/benefit considerations of a new formulation of wheat-based biscuit supplemented with different amounts of chia flour, LWT_Food Science and Technology, 73, pp. 528-535, DOI: 10.1016/j.lwt.2016.06.056.

Milla P.G., Penalver R., Nieto G. (2021), Health benefits of uses and applications of Moringa oleifera in bakery products, Plants, 10(2), pp. 318, DOI: 10.3390/plants10020318.

Mohapatra D., Mishra S., Sutar N. (2010), Banana and its by-product utilisation: an overview, Journal of Scientific \& Industrial Research, 69, pp. 323-329.

Moosavi-Nasab M., Shad E., Ziaee E., Yousefabad S.H.A., Golmakani M.T., Azizinia M. (2016), Biodegradable chitosan coating incorporated with black pepper essential oil for of common carp (Cyprinus carpio) during refrigerated storage, Journal of Food Protection, 79(6), pp. 986-993, DOI: 10.4315/0362-028X.JFP-15-246.

de Moraes Crizel, T., de Oliveira Rios, A., D. Alves, V., Bandarra N., Moldão-Martins M., Flores S.H. (2018), Biodegradable films based on gelatin and papaya peel microparticles with antioxidant properties. Food and Bioprocess Technology, 11, pp. 536-550, DOI: 10.1007/s11947-017-2030-0.

Mudgil D., Barak S., Khatkar B.S., (2016), Optimization of textural properties of noodles with soluble fiber, dough mixing time and different water levels, Journal of Cereal Science, 69, pp. 104-110, DOI: 10.1016/j.jcs.2016.02.015.

Mulyaningsih A.P., Yetti R.D., Rivai H. (2020), Phytochemical and pharmacological review of Maja (Aegle marmelos), World Journal of Pharmacy and Pharmaceutical Sciences, 9(9), pp. 19-42, DOI: 10.20959/wjpps20209-17045.

Nagai T., Yukimoto T. (2003), Preparation and functional properties of beverages made from sea algae, Food Chemistry, 81, pp. 327-332, DOI: 10.1016/S0308-8146(02)00426-0.

Nagai T., Suzuki N., Nagashima T. (2006), Angiotensin I-converting enzyme inhibitory activities of beverages made from sea algae and commercially available tea extracts, Journal of Food, Agriculture and Environment, 4, pp. 17-19.

Neira L.M., Agustinelli S.P., Ruseckaite R.A., Martucci J.F. (2019), Shelf life extension of refrigerated breaded hake medallions packed into active edible fish gelatin films, Packing Technology and Science, 32(9), pp. 471-480, DOI: 10.1002/pts.2450.

Nisar T., Yang X., Alim A., Iqbal M., Wang Z.C., Guo Y. (2019), Physicochemical responses and microbiological changes of bream (Megalobrama ambycephala) to pectin based coatings enriched with clove essential oil during refrigeration, International Journal of Biological Macromolecules, 124(1), pp. 1156-1166, DOI: 10.1016/j.ijbiomac.2018.12.005.

Nogueira G.F., Fakhouri F.M., de Oliveira R.A. (2019), Effect of incorporation of blackberry particles on the physicochemical properties of edible films of arrowroot starch, Drying Technology, 37(4), pp. 448-457, DOI: 10.1080/07373937.2018.1441153.

Oh H.K., Lim H. (2011), Effects of hamburger patties added sea tangle (Laminaria japonica) powder and/or cooked rice on postprandial blood glucose and lipid levels, Journal of the Korean Society of Food Science and Nutrition, 40(6), pp. 809-817, DOI: 10.3746/JKFN.2011.40.6.809. 
Ogunsina B.S., Radha C., Indrani D. (2011), Quality characteristics of bread and cookies enriched with debittered Moringa oleifera seed flour, International Journal of Food Science and Nutrition, 62(2), pp. 185-194, DOI: 10.3109/09637486.2010.526928.

Orona-Tamayo D., Valverde M.E., Paredes-Lopez O. (2017), Chia - the new golden seed for the 21st century: nutraceutical properties and technological uses, In: Sustainable Protein Sources (Nadathur S.R., Wanasundara P.K.J.P.D., Scanlin L., eds.), Academic Press, pp. 265-281, DOI: 10.1016/B978-0-12-802778-3.00017-2.

Ozcan M.M., Arslan D. (2011), Antioxidant effect of essential oils of rosemary, clove and cinnamon on hazelnut and poppy oils, Food Chemistry, 129(1), pp. 171-174, DOI: 10.1016/j.foodchem.2011.01.055.

Othman N.A., Manaf M.A., Harith S., Ishak W.R. (2018), Influence of avocado puree as a fat replacer on nutritional, fatty acid, and organoleptic properties of low-fat muffins, Journal of the American College of Nutrition, 37, pp. 583-588, DOI: 10.1080/07315724.2018.1451408.

Pasqualone A., De Angelis D., Squeo G., Difonzo G., Caponio F., Summo C. (2019a), The effect of the addition of Apulian black chickpea flour on the nutritional and qualitative properties of durum wheat-based bakery products, Foods, 8(10), 504, DOI: 10.3390/foods8100504.

Pasqualone A., Makhlouf F.Z., Barkat M., Difonzo G., Summo C., Squeo G., Caponio F. (2019b) Effect of acorn flour on the physico-chemical and sensory properties of biscuits, Heliyon, 5(8), e02242, DOI: 10.1016/j.heliyon.2019.e02242.

Patel S. (2015), Plant essential oils and allied volatile fractions as multifunctional additives in meat and fish-based food products: a review, Food Additives \& Contaminants. Part A, Chemistry, Analysis, Control, Exposure \& Risk Assessment, 32(7), pp. 1049-1064, DOI: 10.1080/19440049.2015.1040081.

Pellegrini M., Lucas-Gonzalez R., Sayas-Barbera E., Fernández-Lopez J., Perez-Alvarez J., Viuda-Martos M. (2018), Quinoa (Chenopodium quinoa Willd) paste as partial fat replacer in the development of reduced fat cooked meat product type pate: Effect on quality and safety, Journal of Food, 16(1), pp. 1079-1088, DOI: 10.1080/19476337.2018.1525433.

Peris M., Rubio-Arraez S., Castello M.L., Ortola M.D. (2019), From the laboratory to the kitchen: New alternatives to healthier bakery products, Foods, 8(12), p. 660, DOI: $10.3390 /$ foods 8120660 .

Potterat O. (2010), Goji (Lycium barbarum and L. chinense): Phytochemistry, pharmacology and safety in the perspective of traditional uses and recent popularity. Planta Medica, 76(1), pp. 7-19, DOI: 10.1055/s-0029-1186218.

Rabie M.M., Faten Y.I., Youssif M.R.G., El-Ragal N.M.E. (2020), Effect of Moringa oleifera leaves and seeds powder supplementation on quality characteristics of cookies, Journal of Food and Dairy Sciences, 11(2), pp. 65-73, DOI: 10.21608/jfds.2020.78888.

Rajiv J., Indrani D., Prabhasankar P., Rao G.V. (2012), Rheology, fatty acid profile and storage characteristics of cookies as influenced by flax seed (Linum usitatissimum), Journal of Food Science and Technology, 49, pp. 587-593, DOI: 10.1007/s13197-011-0307-2.

Rao B.D., Anis M., Kalpana K., Sunooj K.V., Patil J.V., Ganesh T. (2016), Influence of milling methods and particle size on hydration properties of sorghum flour and quality of sorghum biscuits, LWT-Food Science and Technology, 67, pp. 8-13, DOI: 10.1016/j.lwt.2015.11.033.

Reihani S.F., Tan T.C., Huda N., Easa A.M. (2014), Frozen storage stability of beef patties incorporated with extracts from ulam raja leaves (Cosmos caudatus), Food Chemistry, 155, 17-23, DOI: 10.1016/j.foodchem.2014.01.027.

Realini C.E., Guardia M.D., Diaz I., Garcia-Regueiro J.A., Arnau J. (2015), Effects of acerola fruit extract on sensory and shelflife of salted beef patties from grinds differing in fatty acid composition, Meat Science, 99, pp. 18-24, DOI: 10.1016/j. meatsci.2014.08.008. 
Rey A.I., Hopia A., Kivikari R., Kähkönen M. (2005), Use of natural food/plant extracts: cloudberry (Rubus Chamaemorus), beetroot (Beta Vulgaris "Vulgaris") or willow herb (Epilobium angustifolium) to reduce lipid oxidation of cooked pork patties. LWT - Food Science and Technology, 38(4), pp. 363-370, DOI: 10.1016/j.lwt.2004.06.010.

Riaz G., Chopra R. (2018), A review on phytochemistry and therapeutic uses of Hibiscus sabdariffa L, Biomedicine \& Pharmacotherapy, 102, pp. 575-586, DOI: 10.1016/j.biopha.2018.03.023.

Ribeiro-Santos R., Andrade M., deMelo N.R., Sanches-Silva A. (2017), Use of essential oils in active food packaging: Recent advances and future trends, Trends in Food Science \& Technology, 61, pp. 132-140, DOI: 10.1016/j.tifs.2016.11.021.

Romanchik-Cerpovicz J.E., Tilmon R.W., Baldree K.A. (2002), Moisture retention and consumer acceptability of chocolate bar cookies prepared with okra gum as a fat ingredient substitute, Journal of the American Dietetic Association, 102, pp. 1301-1303, DOI: 10.1016/S0002-8223(02)90287-7.

Roohinejad S., Koubaa M., Barba F.J., Saljoughian S., Amid M., Greiner R. (2017), Application of seaweeds to develop new food products with enhanced shelf-life, quality and healthrelated beneficial properties, Food Research International, 99 (Pt 3), pp. 1066-1083, DOI: 10.1016/j.foodres.2016.08.016.

Qi S., Zhou D. (2012), Lotus seed epicarp extract as potential antioxidant and antiobesity additive in Chinese Cantonese sausage, Meat Science, 93(2), pp. 257-262, DOI: 10.1016/j.meatsci.2012.09.001.

Qian D., Zhao Y., Yang G., Huang L. (2017), Systematic review of chemical constituents in the genus Lycium (Solanaceae), Molecules, 22(6), Article 911, DOI: 10.3390/molecules22060911.

Quiles A., Llorca E., Schmidt C., Reißner A.M., Struck S., Rohm H., Hernando I. (2018), Use of berry pomace to replace flour, fat or sugar in cakes, International Journal of Food Science and Technology, 53, pp. 1579-1587, DOI: 10.1111/ijfs.13765.

Sarkar T., Salauddin M., Chakraborty R. (2020), In-depth pharmacological and nutritional properties of bael (Aegle marmelos): A critical review, Journal of Agriculture and Food Research, 2, 100081, DOI: 10.1016/j.jafr.2020.100081.

Sakac M., Pestoric M., Misan A., Nedeljkovic N., Jambrec D., Jovanov P., Banjac V., Torbica A., Hadnadev M., Mandicet A. (2015), Antioxidant capacity, mineral content and sensory properties of gluten-free rice and buckwheat cookies, Food Technology and Biotechnology, 53, pp. 38-47, DOI: 10.17113/ftb.53.01.15.3633.

Sapper M., Chiralt A. (2018), Starch-based coatings for preservation of fruits and vegetables, Coatings, 8(5), p. 152, DOI: 10.3390/coatings8050152.

Sengev A.I., Abu J.O., Gernah D.I. (2013), Effect of Moringa oleifera leaf powder supplementation on some quality characteristics of wheat bread, Food and Nutrition Sciences, 4(3), pp. 270-275, DOI: 10.4236/fns.2013.43036.

Sharma G., Lakhawat S. (2017), Development, quality evaluation and acceptability of pumpkin seed flour incorporated in gravy, Journal of Nutrition \& Food Sciences, 7, p. 613, DOI: $10.4172 / 2155-9600.1000613$.

Schomburg L., Kohrle J. (2008), On the importance of selenium and iodine metabolism for thyroid hormone biosynthesis and human health, Molecular Nutrition \& Food Research, 52(11), pp. 1235-1246, DOI: $10.1002 / \mathrm{mnfr} .200700465$.

Sciarini L.S., Ribotta P.D., Leon A.E., Perez G.T. (2010), Influence of gluten-free flours and their mixtures on batter properties and bread quality, Food Bioprocess and Technology, 3, pp. 577-585, DOI: 10.1007/s11947-008-0098-2.

Shan B., Cai Y.Z., Brooks J.D., Corke H. (2011), Potential application of spice and herb extracts as natural preservatives in cheese, Journal of Medicinal Food, 14(3), pp. 284-290. DOI: 10.1089/jmf.2010.0009. 
Shannon E., Abu-Ghannam N. (2019), Seaweeds as nutraceuticals for health and nutrition, Phycologia, 58(5), pp. 563-577, DOI: 10.1080/00318884.2019.1640533.

da Silva B.P., Anunciaçao P.C., Matyelka J.C.D.S., Della Lucia C.M., Martino H.S.D., PinheiroSant'Ana H.M. (2017), Chemical composition of Brazilian chia seeds grown in different places. Food Chemistry, 221, pp. 1709-1716, DOI: 10.1016/j.foodchem.2016.10.115.

de Souza N.C.O., de Oliveira L.D.L., de Alencar E.R., Moreira G.P., dos Santos Leandro E., Ginani V.C., Zandonadi R.P. (2018), Textural, physical and sensory impacts of the use of green banana puree to replace fat in reduced sugar pound cakes, LWT-Food Science and Technology, 89, pp. 617-623, DOI: 10.1016/j.lwt.2017.11.050.

Sojic B., Tomovic V., Kocic-Tanackov S., Skaljac S., Ikonic P., Dzinic N., Zivkovic N., Jokanovic M., Tasic T., Kravic S. (2015), Effect of nutmeg (Myristica fragrans) essential oil on the oxidative and microbial stability of cooked sausage during refrigerated storage, Food Control, 54, pp. 282-286, DOI: 10.1016/j.foodcont.2015.02.007.

Souza C.V.B., Bellucci E.R.B., Lorenzo J.M., Barretto A.C.D.S. (2019), Low-fat Brazilian cooked sausage-Paio - with added oat fiber and inulin as a fat substitute: effect on the technological properties and sensory acceptance, Food Science and Technology, 39, pp. 295-303, DOI: 10.1590/fst.03618.

Stephen A.M., Champ M.M.J., Cloran S.J., Fleith M., van Lieshout L., Heddie Mejborn, Burley V.J. (2017), Dietary fibre in Europe: current state of knowledge on definitions, sources, recommendations, intakes and relationships to health, Nutrition Research Reviews, 30(2), pp. 149-190, DOI: 10.1017/S095442241700004X.

Suhag R., Kumar N., Petkoska A.T., Upadhyay A. (2020), Film formation and deposition methods of edible coating on food products: A review, Food Research International, 136, 109582, DOI: $10.1016 /$ j.foodres.2020.109582.

Talukder S. (2015), Effect of dietary fiber on properties and acceptance of meat products: a review, Critical Reviews in Food Science and Nutrition, 55(7), pp. 1005-1011, DOI: 10.1080/10408398.2012.682230.

Tajik H., Aminzare M., Mounesi-Raad T., Hashemi M., Hassanzad-Azar H., Raeisi M., Naghili H. (2015), Effect of Zataria multiflora Boiss essential oil and grape seed extract on the shelf life of raw buffalo patty and fate of inoculated Listeria monocytogenes, Journal of Food Processing and Preservation, 39(6), pp. 3005-3013, DOI: 10.1111/jfpp. 12553.

Taneva I., Zlatev Z. (2020), Total phenolic content and antioxidant activity of yoghurt with goji berries (Lycium barbarum), Scientific Study \& Research: Chemistry \& Chemical Engineering, Biotechnology, Food Industry, 21(1), pp. 125-131. http://pubs.ub.ro/dwnl.php?id=CSCC6202001V01S01A0011.

Tayel A.A., Hussein H., Sorour N.M., El-Tras W.F. (2015), Foodborne pathogens prevention and sensory attributes enhancement in processed cheese via flavoring with plant extracts, Journal of Food Science, 80(12), M2886 - M2891, DOI: 10.1111/1750-3841.13138.

Venthodika A., Chhikara N., Mann S., Garg M.K., Sofi S.A, Panghal A. (2021), Bioactive compounds of Aegle marmelos L., medicinal values and its food applications: A critical review, Phytotherapy Research, 35(4), pp. 1887-1907, DOI: 10.1002/ptr.6934.

Vilar E., Ouyang H., O'Sullivan M., Kerry J., Hamill R., O’Grady M., Mohammed H., Kilcawley K. (2020), Effect of salt reduction and inclusion of $1 \%$ edible seaweeds on the chemical, sensory and volatile component profile of reformulated frankfurters. Meat Science, 161, 108001. DOI: 10.1016/j.meatsci.2019.108001.

Wang K., Fei L.U., Zhe L.I., Zhao L., Han C. (2017), Recent developments in gluten-free bread baking approaches: a review, Food Science and Technology, 37 supl.1 DOI: 10.1590/1678-457x.01417.

Watanabe K., Kawanishi-Asaoka M., Myojin C., Awata S., Ofusa K., Kodama K. (2014), Amino acid composition, oxidative stability, and consumer acceptance of cookies made with 
quinoa flour, Food Science and Technology Research, 20(3), pp. 687-691, DOI: $10.3136 /$ fstr.20.687.

Wu J., Ge S., Liu H., Wang S., Chen S., Wang J., Li J., Zhang Q. (2014), Properties and antimicrobial activity of silver carp (Hypophthalmichthys molitrix) skin gelatin-chitosan films incorporated with oregano essential oil for fish preservation, Food Packaging and Shelf Life, 2(1) pp. 7-16, DOI: 10.1016/j.fps1.2014.04.004.

Ullikashi K.Y., Kammar M.R. Lokapure S.R. (2017), Development of value added products from Bael fruit (Aegle marmelos), International Journal of Current Microbiology and Applied Sciences, 6(7), pp. 2652-2659.

Umesha S.S., Manohar R.S., Indiramma A.R., Akshitha S., Naidu K.A. (2015), Enrichment of biscuits with microencapsulated omega-3 fatty acid (alpha-linolenic acid) rich Garden cress (Lepidium sativum) seed oil: Physical, sensory and storage quality characteristics of biscuits. LWT-Food Science and Technology, 62, pp. 654-661, DOI: 10.1016/j.lwt.2014.02.018.

Yan J., Luo Z., Ban Z., Lu H., Li D., Yang D., Aghdam M.S., Li L. (2019), The effect of the layerby-layer (LBL) edible coating on strawberry quality and metabolites during storage, Postharvest Biology and Technology, 147, pp. 29-38, DOI: 10.1016/j.postharvbio.2018.09.002.

Yang Y., Ma S., Wang X., Zheng X. (2017), Modification and application of dietary fiber in food, Journal of Chemistry, Article ID 9340427, DOI: 10.1155/2017/9340427.

Yang H.S., Kim G.D., Choi S.G., Joo S.T. (2010), Physical and sensory properties of low fat sausage amended with hydrated oatmeal and various meats, Korean Journal for Food Science of Animal Resources, 30(3), pp. 265-272, Available at: https://pdfs.semanticscholar.org/eb4d/54ae72fd19ffce3 febd75b570e645e16859d.pdf.

Yogesh K., Ali J. (2014), Antioxidant potential of thuja (Thuja occidentalis) cones and peach (Prunus persia) seeds in raw chicken ground meat during refrigerated $\left(4 \pm 1{ }^{\circ} \mathrm{C}\right)$ storage, Journal of Food Science and Technology, 51(8), pp. 1547-1553, DOI: 10.1007/s13197012-0672-5. 